\title{
THE CUSTOMARY INTERNATIONAL LAW OF STATE-SPONSORED INTERNATIONAL ABDUCTION AND UNITED STATES COURTS
}

\author{
JONATHAN A. GLUCK
}

INTRODUCTION

\begin{abstract}
On April 2, 1990, around 7:45 p.m., Dr. Humberto AlvarezMachain was relaxing in his office in Guadalajara, Mexico, having just finished treating a patient. Suddenly, five or six armed men burst into his office. One showed him a badge that appeared to be that of the Mexican federal police. Another placed a gun to Dr. Alvarez-Machain's head and told him to cooperate "or he would be shot." The men then took Dr. Alvarez-Machain to a house where he was forced to lie on the floor facedown for two or three hours. His captors shocked him several times with an "electric shock apparatus" and injected him twice with a substance that made him feel "light-headed and dizzy." Later, Dr. AlvarezMachain was transported by car to Leon, where he and his captors boarded a plane headed for El Paso, Texas. When they arrived in El Paso on April 3, agents of the U.S. Drug Enforcement Agency (DEA) were waiting to arrest Dr. Alvarez-Machain ${ }^{3}$ for his alleged involvement in the 1986 torture and murder of DEA agent Enrique Camarena. ${ }^{4}$
\end{abstract}

1. United States v. Caro-Quintero, 745 F. Supp. 599, 603 (C.D. Cal. 1990), affd sub nom. United States v. Alvarez-Machain, 946 F.2d 1466 (9th Cir. 1991), rev'd, 112 S. Ct. 2188 (1992).

2. Id.

3. Id.

4. The indictment returned against Dr. Alvarez-Machain charged him with conspiracy to commit violent acts and violent acts in furtherance of an enterprise engaged in racketeering activity (18 U.S.C. $\$ \$ 371,1959$ (1988)), conspiracy to kidnap a federal agent (18 U.S.C. $\S 1201(\mathrm{c})$ (1988)), kidnapping a federal agent (18 U.S.C. $\S 1201$ (a)(5) (1988)), and felony murder (18 U.S.C. $\S \S 1111(\mathrm{a}), 1114$ (1988 \& Supp. IV 1992)). United States v. Alvarez-Machain, 112 S. Ct. 2188, 2190 n.1 (1992). On December 14, 1992, after Dr. Alvarez-Machain's case was remanded to the district court, that court acquitted Dr. Alvarez-Machain of all charges and ordered his release on the ground that the government had failed to establish a prima facie case. Manuel R. Angulo \& James D. Reardon, Jr., The Apparent Political and Administrative Expediency Exception Established by the Su- 
The kidnapping of Dr. Alvarez-Machain from Mexico was a state-sponsored international abduction. The United States, through its paid agents, removed a foreign national from his country and brought him to the United States to stand trial. International abduction is not a recent phenomenon; incidents of such conduct can be found as early as $1835^{5}$ and have occurred fairly consistently worldwide throughout the last 160 years. ${ }^{6}$ Although extradition treaties abound, ${ }^{7}$ their procedures are cumbersome, and they are often ineffective tools for attaining jurisdiction over an individual. ${ }^{8}$ As a result, governments have sometimes resorted to extraterritorial apprehension and arrest in order to obtain jurisdiction over wanted individuals, and there is little reason to believe that such conduct will not continue in the future.

preme Court in United States v. Humberto Alvarez-Machain to the Rule of Law as Reflected by Recognized Principles of International Law, 16 B.C. INT'L \& COMP. L. REv. 245, 284 (1993).

5. State v. Brewster, 7 Vt. 118 (1835).

6. A short list of reported cases involving abductions in which the United States has been a party includes Matta-Ballesteros v. Henman, 896 F.2d 255 (7th Cir.), cert. denied, 498 U.S. 878 (1990); United States v. Reed, 639 F.2d 896 (2d Cir. 1981); United States ex rel. Lujan v. Gengler, 510 F.2d 62 (2d Cir.), cert. denied, 421 U.S. 1001 (1975); United States v. Toscanino, 500 F.2d 267 (2d Cir. 1974); United States v. Insull, 8 F. Supp. 310 (N.D. Ill. 1934); and United States v. Unverzagt, 299 F. 1015 (W.D. Wash. 1924), aff'd sub nom. Unverzagt v. Benn, 5 F.2d 492 (9th Cir.), cert. denied, 269 U.S. 566 (1925).

7. The United States, for example, has extradition treaties with 103 nations. U.S. Has No Need for Official Kidnappings, ATLANTA CONST., Apr. 16, 1993, at A10.

8. Some states do not possess an effective police force and cannot locate persons within their boundaries, and thus cannot honor requests for extradition. In addition, many extradition treaties do not provide for the extradition of nationals. For example, the U.S.France Extradition Treaty of 1909 stated that "neither of the contracting Parties shall be bound to deliver up its own citizens or subjects under the stipulations of this convention." Valentine v. United States ex rel. Neidecker, 299 U.S. 5, 7 (1936) (quoting Extradition Treaty of 1909, Jan. 6, 1909, U.S.-Fr., art. 5, 37 Stat. 1526)); see also, e.g., Extradition Treaty, May 4, 1978, U.S.-Mex., art. 9, 31 U.S.T. 5059, 5065 (containing similar provision). Other problems include the fact that extradition treaties may become suspended due to a break in the diplomatic relations between the signatory states and the fact that an extradition treaty might not permit extradition for the specific crime for which a state seeks extradition. Richard Downing, Note, The Domestic and International Legal Implications of the Abduction of Criminals from Foreign Soil, 26 STAN. J. INT'L L. 573, 576 (1990).

9. Consider, for example, the following hypothetical abduction suggested by Professor Abraham Abramovsky:

As the night turns into morning, four heavy-set men burst into Aramco's corporate headquarters in Houston, Texas, and point an AK-47 at the head of Aramco's CEO. "Do as you're told and nobody will get hurt," they explain, and they deposit him in the back of a waiting automobile. The captive is informed that he is under indictment for complicity in plundering of natural re- 
The relative frequency of international abductions notwithstanding, it is widely accepted that such abductions violate some of the most basic tenets of international law. Indeed, it is well settled that international law prohibits a state from exercising its sovereignty in the territory of another state..$^{10}$ International law simply does not permit a state to send officials or agents into the territory of another state to either kidnap or arrest a person from that state. ${ }^{11}$ Such abductions have been condenned not only by the states froin which the persons have been seized, but also by the international cominunity at large. ${ }^{12}$

Nonetheless, the agreement that these abductions violate international law has not generated any corresponding scholarly consensus as to the appropriate remedy for the violation. Although their conclusions rest on varied premises, several scholars have argued that the return of the individual is not an accepted customary international law remedy. Professor Bassiouni, for example, writes that " $[t]$ he only established remedies are reparations and diplonnatic apologies; the additional remedy of the return of the person seized unlawfully is not yet recognized, although some courts have seen fit to apply it."13 Underlying this conclusion ap-

sources from the Rumaila oil fields in violation of the sovereignty of Iraq. The four abductors tie the astonished CEO up and beat him about the head and body with blunt instruments. They smuggle him into Iran with the acquiescence of Iranian authorities, and with their assistance he is placed under arrest by Iraqi law enforcement agents. Finally, they bring him before a court in Baghdad, where he is accorded all the due process rights to which he is entitled under Iraqi criminal law and promptly sentenced to prison. The U.S. State Department adamantly protests his apprehension and capture as a violation of U.S. sovereignty and territorial integrity, but the Iraqis respond with nothing less than unqualified scorn. Meanwhile, a U.S. citizen finds himself alone in the vagaries of the Iraqi criminal justice system.

Abraham Abramovsky, Extraterritorial Abductions: America's "Catch and Snatch" Policy Run Amok, 31 VA. J. INT'L L. 151, 151 (1991); see also D. Cameron Findlay, Abducting Terrorists Overseas for Trial in the United States: Issues of International and Domestic Law, 23 TEX. INT'L L.J. 1, 16 (1988).

10. See infra Section $\mathrm{I}(\mathrm{A})$.

11. Id.

12. See S.C. Res. 138, U.N. SCOR, 15th Sess., Supp. for Apr.-June 1960, at 35, U.N. Doc. S/4349 (1960). In response to the Israeli abduction of Nazi war criminal Adolf Eichmann from Argentina, the U.N. Security Council passed a resolution in which it "[d]eclare[d] that acts such as those under consideration which affect the sovereignty of a member state and therefore cause friction, may, if repeated, endanger international peace and security."

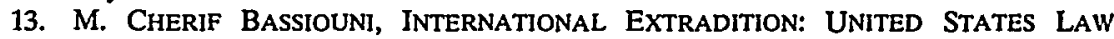
AND PRACTICE 217 (1987). Ironically, however, the very cases used by Bassiouni to conclude that international law does not require the return of the abducted individual were cited by the Supreme Court in the Alvarez-Machain case in noting that such conduct 
pears to be the imphicit assumption either that there are not enough cases of return to make it an accepted remedy or that in cases in which the abducting state has chosen to return the individual, it has not believed that it was legally obligated to do so. ${ }^{14}$ Similarly, Jonathan Bush argues that " $[t]$ raditional international law [ fails] to provide remedies for victims"1s and that an "aggrieved country [does] not enjoy a remedy as of right, but only if compliance benefits the offending country."16 According to Bush, there is an "absence of a principled distinction between cases where a reinedy is obtained and those lacking a reinedy."17 Consequently, disparate results are explained by the political interests involved in each case. ${ }^{18}$ Finally, Andreas Lowenfeld has noted that arguments for the return of the individual "have succeeded only intermittently, and usually in a semipolitical, seinilegal context." 19

Other scholars have argued, however, that the return of the abducted individual is required under international law..$^{20}$ As early as 1935, Lawrence Preuss argued that "[s]uch a violation of foreign territory undoubtedly engages the responsibility of the state of arrest, which is under a clear duty to restore the prison-

"may show the practice of nations under customary international law." United States v. Alvarez-Machain, 112 S. Ct. 2188, 2196 n.15 (1992).

14. But see infra Section III.

15. Jonathan A. Bush, How Did We Get Here? Foreign Abduction After AlvarezMachain, 45 STAN. L. REV. 939, 947 (1993).

16. Id. at 948 .

17. Id. at 947 .

18. This Note takes issue with Bush's conclusion and argues that there are basic principled distinctions that can and must be drawn among international abduction cases. As discussed later, most international abduction cases do not involve any breach of international law and therefore the issue of "remedy" is irrelevant. For example, neither the abduction of Ker nor that of Eichmann, incidents that Bush uses to illustrate his point that international law does not recognize any "remedy," id. at 948, involved any breach of international law that required repatriation. See infra note 26.

19. Andreas F. Lowenfeld, U.S. Law Enforcement Abroad, 84 AM. J. INT'L L. 444, 475 (1990).

20. See Keith Highet \& George Kahale III, International Decisions, 86 AM. J. INT'L L. 811, 815 (1992); Claire E. Lewis, Unlawful Arrest: $A$ Bar to the Juridiction of the Court, or Mala Captus Bene Detentus? Sidney Jaffe: A Case in Point, 28 CRIM. L.Q. 341, 368 (1985-1986); Felice Morgenstern, Jurisdiction in Seizures Effected in Violation of International Law, 29 BRIT. Y.B. INT'L L. 265, 265 (1952); Paul O'Higgins, Unlawful Seizure and Irregular Extradition, 36 BRIT. Y.B. INT"L L. 279, 293 (1960) ("British practice is in accordance with the principle that in case of apprehension in violation of international law there is an obligation upon the arresting state to restore the person arrested."). 
er. ..."21 Preuss argued further that "[t] the abducted person] appears to have been almost uniformly acknowledged in cases where the injured State has made a diplomatic reclamation." 22 Similarly, F.A. Mann has written that "[t]he normal and generally accepted remedy in the event of a wrongful abduction is the return of the victim.",23

This Note examines the historical cases of state-sponsored international abduction and argues that customary international law requires the remedy of restitutio in integrum ${ }^{24}$ that is, when an asylum state that did not in any manner partake in the abduction protests the kidnapping and demands return, the abducting state is obligated to return the individual to the asyluin state..$^{25}$ In addition, this Note argues that United States courts have misconstrued their own power in holding that they are unable to effect this remedy. Because there is no United States law, either statutory or judicially created, that directly bars a district court from ordering the return of an abducted individual, United States courts have the power to order the return of a person based on the force of international law within United States law. ${ }^{26}$ Part I of this

21. Lawrence Preuss, Kidnapping of Fugitives from Justice on Foreign Territory, 29 AM. J. INT'L L. 502, 505 (1935).

22. Id.

23. F.A. Mann, Reflections on the Prosecution of Persons Abducted in Breach of International Law, in INTERNATIONAL LAW AT A TME OF PERPLEXITY 411 (Yoram Dinstein ed., 1989).

24. "In the civil law, restoration or restitution to the previous condition." BLACK's LAW DICTIONARY 1313 (6th ed. 1990).

25. In this Note, the term "asylum state" refers to the state from which an individual was taken; the term "abducting state" refers to the state that committed the abduction.

26. Generally, national courts have not directly addressed the international law issues discussed in this Note. Instead, they have considered the issue of international abduction solely in terms of their jurisdiction over the abducted individual. They simply have not framed the issue as a question of the international responsibility of the state for the abduction. See Ker v. Illinois, 119 U.S. 436, 443 (1886); Re Argoud, 45 I.L.R. 90 (Cass. Crim. 1964) (Fr.); Abrahams v. Minister of Justice, 1963 (4) SA 542 (S. Afr.), reprinted in S. Afr. L. Rep. (1963); Ex Parte Scott, 109 Eng. Rep. 166 (K.B. 1829). In virtually every case, the national court has held that jurisdiction is not affected by the circumstances of the apprehension. Representative of this position is the language of the district court of Israel in the Eichmann case. It stated that

[t]he Courts in England, the United States and Israel have constantly held that the circumstances of the arrest and the mode of bringing of the accused into the territory of the State have no relevance to his trial, and they have consistently refused in all instances to enter upon an examination of these circumstances.

Attorney Gen. v. Eichmann, 36 I.L.R. 18, 59 (Isr. Dist. Ct. 1961); see also Ker, 119 U.S. at 444 ("There are authorities of the highest respectability which hold that such forcible 
abduction is no sufficient reason why the party should not answer when brought within the jurisdiction of the court which has the right to try him for such an offence.....").

The language of these cases appears to suggest that even in cases of a violation of international law, the exercise of jurisdiction is allowed, and therefore that international law imposes no duty of return. However, the broad language used by these courts was not justified by the circumstances of those specific abductions. With the exception of the well-known Eichmann case, none of these widely cited cases involved a breach of international law sufficient to give rise to state responsibility. In $\mathrm{Ker}$, the abduction was committed by a private individual, Ker, 119 U.S. at 443 ("[T]he facts show that it was a clear case of kidnapping ... without any pretence of authority ... from the government of the United States."); in Ex Parte Scott, Abrahams, and Re Argoud, there was no evidence that the asylum state ever protested the arrest on its territory. In Eichmann, although the Israeli abduction from Argentina clearly violated international law, Argentina explicitly waived its right to assert responsibility:

By the joint decision of the Governments of Argentina and Israel of August 30, 1960 "to regard as closed the incident that arose out of the action taken by citizens of Israel, which infringed the fundamental right of the State of Argentina," the country whose sovereignty was violated has waived its claims, including its claim for the return of the accused, and any violation of international law which might have been involved in the "incident" has been "cured."

Eichmann, 36 I.L.R. at 70. Consequently, these cases' conclusions that jurisdiction exists regardless of the facts of the extraterritorial abduction (i.e., even if there was a breach of international law) are pure dicta.

Given that there was no violation of international law in these cases, these courts were arguably correct in asserting jurisdiction over the accused. However, these cases certainly do not constitute authority for the broader proposition that jurisdiction exists in all cases or that international law does not impose a duty of return. The apparent tension between the duty of the abducting state to repatriate the individual and the power and apparent "right" of the domestic court to assert jurisdiction thus may not be as severe as the language of these cases suggests. In short, these cases do not establish that mala captus, bene detentus ("wrongfully taken, rightfully held") is the governing international norm in cases of international abduction in violation of international law. See Aaron Schwabach \& S.A. Patchett, Doctrine or Dicttm: The Ker-Frisbie Doctrine and Official Abductions Which Breach International Law, 25 U. MIAMI INTER-AM. L. REV. 19, 50-53 (1993).

Conceptually, moreover, there is a distinction between the issue of jurisdiction over an accused and the question of international law remedies. The first is concerned with the power of the domestic court over the individual, the second with the legal obligation of the state entity in its relations with other states. Therefore, the existence of jurisdiction in certain cases of state-sponsored international abduction in violation of international law does not compel the conclusion that international law does not demand return of the individual. Rather, it merely acknowledges that the power of domestic courts is not abridged by the requirements of international law in these particular domestic legal systems.

It could be the case that even if a domestic court could exercise jurisdiction, international law would impose a duty of return on the state entity. This obligation could be discharged in any manner that the state's internal legal or political processes allow. Thus, for example, in the event that the domestic court could not effectuate the international law remedy, the burden of compliance would then rest with the executive or legislative branch. In this sense, the power of a domestic court to exercise jurisdiction and the requirements of international law are not diametrically opposed. If, however, the domestic law of a state does not require the exercise of jurisdiction and allows a court to take 
Note addresses the issue of state responsibility in cases of international abduction. It discusses the types of conduct that create responsibility for the abducting state and give rise to the obligation of returning the individual. It also considers the factors that may exculpate a state and preclude the asylum state from asserting responsibility. Part II considers the issue of remedies under international law. Part III argues that in the specific context of state-sponsored international abduction, state practice, as evidenced by diplomatic protests and reclamations, and by some national court judgments, firmly reflects an international custom of repatriating the abducted individual to the asylum state. Part IV discusses the power of United States courts to effectuate return of the individual and to make the United States comply with its international law obligations. ${ }^{27}$

\section{STATE RESPONSIBILITY FOR INTERNATIONAL ABDUCTIONS}

\section{A. The Violation of International Law by International Abductions}

International law is composed of both "primary" and "secondary" legal principles. Primary principles are those that establish the legality or illegality of state conduct or the content of the obligations that delimit the permissible range of state action. ${ }^{28}$ As the International Law Commission's Draft Articles on State Responsibility note, "primary" rules are those that "defin[e] the rules of international law which, in one or another sector of interState relations, impose specific obligations on States . ..."29 The law of state responsibility is not one of these primary rules; rather,

notice of, and administer, international law, then declining to exercise jurisdiction may simply constitute a shortcut for bringing the state into compliance with its international legal obligations without having to rely on the executive or legislative branch.

In short, the principle of mala captus, bene detentus has not been established in cases in which the abduction violated international law. Even if one assumes that the cases cited above did establish that jurisdiction existed despite a breach of international law, this merely resolves a question of the domestic court's power; it does not resolve the question of the proper international law remedy.

27. The scope of this Note is limited to the customary international law remedy of states in cases of state-sponsored international abduction. It does not venture into the issue of what international human rights issues are raised by such abductions.

28. See OsCar Schachter, International. LAW In Theory and Practice 202 (1991).

29. THE INTERNATIONAL LAW COMMISSION'S DRAFT ARTICles ON STATE RESPONSIBILITY 39 (Shabtai Rosenne ed., 1991) [hereinafter DRAFT ARTICLES]. 
it consists of those secondary legal principles that are "concerned with determining the legal consequences of failure to fulfill obligations established by the 'primary' rules." ${ }^{.30}$ The law of state responsibility thus encompasses both the obligation to effect a suitable remedy for a violation of international law and the nature of the remedy itself. ${ }^{31}$ As Ian Brownlie has written, "In international relations as in other social relations, the invasion of the legal interest of one subject of the law by another legal person creates responsibility in various forms determined by the particular legal system." M2 More specifically, "in principle an act or omission which produces a result which is on its face a breach of a legal obligation gives rise to responsibility in international law, whether the obligation rests on treaty, custom, or some other basis."${ }^{33}$ This principle is reflected in article 1 of the Draft Articles on State Responsibility, which states that "[e]very internationally wrongful act of a State entails the international responsibility of that State." ${ }^{34}$ According to the official commentary, this article reflects " $[t]$ he principle that any conduct of a State which inter-

30. Id.; see id. at 40 ("[I]t is one thing to define a rule and the obligation it imposes, and another to determine whether there has been a breach of that obligation and what should be the consequences of the breach."); J.G. STARKE, INTRODUCTION TO INTERNATIONAL LAW 294 (10th ed. 1989); Pierre-Marie Dupuy, The International Law of State Responsibility: Revolution or Evolution?, 11 MICH. J. INT"L L. 105, 105 (1989) ("The origin of the responsibility arose in the commission of a wrongful act by a state, in particular, an act or omission by the state violating to its international obligation vis-à-vis another state.").

31. See 2 Restatement (ThiRd) OF the Foreign Relations LaW of the UnITED STATES \$ 901 (1987) [hereinafter RESTATEMENT (THIRD) OF FOREIGN RELATIONS] ("Under international law, a state that has violated a legal obligation to another state is required to terminate the violation and, ordinarily, to make reparation, including in appropriate circumstances restitution or compensation for loss or injury."); Inter-American Juridical Comm., Legal Opinion on the Decision of the U.S. Supreme Court in the Alvarez-Machain Case, 13 HUM. RTS. L.J. 395, 397 (1992) ("Pursuant to the rules governing state responsibility in international law, any state that violates an international obligation must make reparations for the consequences of the violation."); see also IAN BRoWNLie, PRINCIPLes of PUblic International Law 434 (4th ed. 1990) ("Responsibility is the necessary corollary of a right. All rights of an international character involve international responsibility. If the obligation in question is not met, responsibility entails the duty to make reparation."); CLYDE EAGLETON, THE RESPONSIBILITY OF STATES IN INTERNATIONAL LAW 22 (1928) ("Responsibility is simply the principle which establishes an obligation to make good any violation of international law producing injury ....").

32. BROWNLIE, supra note 31 , at 432 .

33. Id. at 436.

34. DRAFT ARTICLES, supra note 29, art. 1, at 43. 
national law characterizes as a wrongful act entails the responsibility of that State in international law . ..."35

It is a well-established primary rule of international law that no state may exercise its police power in the territory of another state without the consent of the host state. ${ }^{36}$ Thus, for example, the Restatement (Third) of the Foreign Relations Law of the United States provides that "[a] state's law enforcement officers may exercise their functions in the territory of another state only with the consent of the other state, given by duly authorized officials of that state. ${ }^{\prime 37}$

It is clear, therefore, that when a state orders its officials into the territory of a foreign state to apprehend an individual without the consent of the asylum state, it violates this principle of international law. ${ }^{38}$ A state also violates this principle when it employs or encourages others to undertake official policy on its behalf. For example, article 8 of the Draft Articles on State Responsibility states that "[t]he conduct of a person or group of persons shall also be considered as an act of the State under international law if ... it is established that such person or group of persons was in fact acting on behalf of that State ...."39 A corollary to this

35. Id.

36. BRowNLIE, supra note 31, at 85; Letter from Lord Monck to Lord Lyons (May 22, 1863), in 1 U.S. DEP'T OF STATE, FOREIGN RELATIONS OF THE UNITED STATES 559 (1863) ("It appears clear that . . two men . . . were removed by force from the State of Michigan to Canada by Canadian constables acting on their own responsibility, and that undoubtedly an infraction of the rights of the United States government was committed by them." (emphasis added)); see also Mann, supra note 23, at $407 \mathrm{n} .2$ (noting that the proposition is "elementary"); 1 L. OPPENHEIM, InTERNATIONAL LAW: A TREATISE 295 (Hersch Lauterpacht ed., 8th ed. 1955) ("A State must not perform acts of sovereignty in the territory of another State.").

37. 1 Restatement (THIRD) OF Foreign RELATIONS, $\&$ 432(2) (1987).

38. OPPENHEIM, supra note 36 , at 295 n.1 ("It is therefore a breach of International Law for a State to send its agents to the territory of another State to apprehend persons accused of having committed a crime."); Lewis, supra note 20, at 343-44 ("The involvement of officials of one country in the crime of kidnapping on the territory of another is a violation of territorial sovereignty . ..."); O'Higgins, supra note 20, at 280; see also Abramovsky, supra note 9, at 194 ("[A]bduction violates the sovereignty and territorial integrity of the asylum state.").

39. DRAFT ARTICLES, supra note 29, art. 8, at 85 . According to the commentary to article 8 , responsibility may arise due to "the conduct of persons . . . or groups of person who have in particular circumstances acted in fact on behalf of the state without, however, having been formally appointed as organs for that purpose under the State's legal system." Id. Thus, under the terms of the Draft Articles, actions by persons operating with a mandate from their state give rise to state responsibility. See BASsIOUNI, supra note 13, at 216 ("[I]t is clear that state responsibility attaches to acts committed by 
principle, however, is that purely "private" abductions do not give rise to a claim of state responsibility. In $S$. v. Ebrahim, for example, the South African court stated,

It is clear from the authorities in English and in American law that the distinction made... between an unlawful abduction made by a private citizen of a person abroad and an abduction made with the connivance of the South African State or its officials is sound and logical. The latter is objectionable because it affects the comity of nations and the international obligations of sovereign States, the former does not. ${ }^{40}$

agents of a state or by private individuals acting for or on behalf of the state."); BROWNLIE, supra note 31, at 160-61; STARKE, supra note 30, at 307.

40. S v. Ebrahim, 1991 (2) SA 553, 559 (S. Afr.), reprinted in S. Afr. L. Rep. (Apr.June 1991). One defense that states have repeatedly asserted in abduction cases is that the kidnapping was carried out by "private persons." In the case of Jacob Solomon, a German emigré who was kidnapped in Switzerland and brought to Germany, the German government initially argued that since there was no evidence that German authorities had participated in the abduction, the government had not violated international law. Preuss, supra note 21, at 504. Similarly, the United States asserted this defense in the Martinez incident, when an individual was taken from Mexico to the United States. Letter from Robert Bacon to Balbino Davalos (June 22, 1906), in 2 U.S. DEP'T OF STATE, ForeIGN RELATIONS OF THE UNITED STATES 1121, 1122 (1906).

A problem that therefore arises in this context is ascertaining which individuals should be considered state agents for purposes of determining state responsibility. It is beyond the scope of this Note, however, to examine the circumstances in which actions by ostensibly private persons might give rise to state responsibility. For a general discussion of "[w] hat can be identified as the machinery of the state," see IAN BROWNLIE, SYSTEM OF LAW OF NATIONS 135-37 (1983). For a discussion of state responsibility issues in the context of "private" bounty hunters, see Perry J. Seaman, Comment, International Bountyhunting: A Question of State Responsibility, 15 CAL. W. INT'L L.J. 397 (1985).

A related issue is the problem posed by "ratification." It has been argued that when a state subsequently prosecutes an individual kidnapped by "private" persons, it "ratifies" the acts of the private individuals and thereby gives rise to a claim of state responsibility. See Mann, supra note 23, at 408. Although Mann's point is well taken, two factors argue against his conclusion. First, no case or instance has been found in which a state has argued that the subsequent prosecution of an individual abducted gives rise to state responsibility. Therefore, state practice does not appear to support this position. Second, since the violation of the asylum state's territorial sovereignty is the underlying wrong, it is difficult to argue that prosecution alone creates responsibility. The prosecution itself does not violate the sovereignty of the asylum state or violate international law. Therefore, it would not seem sufficient, in and of itself, to give rise to state responsibility. 


\section{B. Defenses to Claims of State Responsibility for International Ab-} ductions

Even when a state's actions would normally create responsibility for an international abduction, certain circumstances may exonerate the state. ${ }^{41}$ The Draft Articles on State Responsibility provide for several situations in which otherwise wrongful acts do not give rise to state responsibility. These exceptions include situations involving consent, ${ }^{42}$ legitimate countermeasures, ${ }^{43}$ force majeure, ${ }^{44}$ distress, ${ }^{45}$ necessity, ${ }^{46}$ and self-defense. ${ }^{47}$

Although these defenses may or may not be applicable in any particular instance, ${ }^{48}$ the issue of consent is central to nearly every case of state-sponsored international abduction. If the asylum state permits a foreign state to exercise its police power in the asylum state's territory, then no issue of state responsibility arises. State practice suggests that in addition to explicit consent, implicit consent may be a defense: if a competent asylum state official partakes in the arrest, even if this arrest is illegal under asylum state law, this involvement is sufficient to constitute consent and to preclude any assertion of responsibility by the asylum state. ${ }^{49}$ In

41. SCHACHTER, supra note 28 , at 203.

42. DRAFT ARTICLES, supra note 29, art. 29, at 313.

43. Id. art. 30 , at 319 .

44. Id. art. 31 , at 326 .

45. Id. art. 32 , at 337.

46. Id. art. 33 , at 351 .

47. Id. art. 34 , at 369 .

48. With the exception of consent, it is beyond the scope of this Note to consider the possible application of these general exculpatory principles to the specific context of international abduction. The extent of at least some of these principles has generated considerable debate. The former legal advisor to the U.S. State Department, Judge Sofaer, for example, has suggested that the right of self-defense might provide justification for international abductions in some circumstances. FBI Authority to Seize Suspects Abroad: Hearing Before the Subcomm. on Civil and Constitutional Rights of the House Comm. on the Judiciary, 101st Cong., 1st Sess. 34-38 (1989) (statement of Abraham D. Sofaer, Legal Advisor, Department of State); see Findlay, supra note 9, at 29-33. However, a 1980 memorandum opinion of the U.S. Department of Justice concluded that "there [do not] appear to be any doctrines of self-help or self-defense applicable in th[e] context [of state-sponsored international abduction]." 4B Op. Off. Legal Counsel 543, 549 (1980). For the purposes of this Note, it suffices to observe that the scope and limits of these exculpatory provisions will continue to evolve. In general, moreover, these defenses may be available to a state in any partictlar case.

49. DRAFT ARTICLES, supra note 29, art. 29, at 316:

[I]n cases involving arrests by organs of one State of persons who were in the territory of another State, it has sometimes been held that the action of the local police in co-operating in the arrest constituted, in those cases, a form of 
United States v. Sobell, for example, the U.S. district court held that when the Mexican police were involved in an abduction from Mexico, the abductee's argument that he should be released was "blocked ... by the rule that even a diplomatic demand for the return of an illegally seized fugitive need not be honored where officials of the asylum state took part in the illegal seizure."50

Moreover, the level of authority possessed by the asylum state official has generally been considered irrelevant in determining whether the state consented to the abduction. Thus, the complicity of even a very ininor official has been considered sufficient. In the case of Savarkar, for example, a British prisoner escaped from a British ship while it was docked at a French port. A French constable who saw the prisoner escaping proinptly apprehended him and returned him to the vessel. When France brought an action in the Permanent Court of Arbitration, the court held that the involvement of this French official precluded any finding that French sovereignty was violated. ${ }^{51}$

Even if a state does not consent to acts that give rise to a claim of responsibility, it may nonetheless waive its rights to such a claim after a breach. Waiver occurs when a state forgoes "the right to assert responsibility and the claims arising therefroin." 52

consent-tacit, but incontestable-by the territorial State and that, consequently, there had been no violation of the territorial sovereignty of that State.

See also Preuss, supra note 21, at 507 (noting that there is "no obligation to surrender the prisoner when officials of the state of asylum have participated in the irregular... arrest").

50. United States v. Sobell, 142 F. Supp. 515, 525 (S.D.N.Y. 1956), affd, 244 F.2d 520 (2d Cir.), cert. denied, 355 U.S. 873 (1957). Similarly, in United States ex rel. Lujan v. Gengler, 510 F.2d 62, 67 (2d. Cir.), cert. denied, 421 U.S. 1001 (1975), the Second Circuit suggested that the involvement of Bolivian authorities in the arrest of the defendant in Bolivia precluded any finding that a violation of international law had occurred.

51. Savarkar Case (Fr. v. Gr. Brit.), Hague Ct. Rep. (Scott) 275, 279 (Perm. Ct. Arb. 1911). Brownlie notes that "[i]t is now generally accepted that the position of an official in the internal hierarchy has no relevance to the question of state responsibility." BROWNLIE, supra note 40 , at 134 . It would therefore appear entirely logical to deduce that the complicity of even a very minor asylum state official in an international abduction would be sufficient to constitute consent of the asylum state and destroy any claim of state responsibility.

52. DRAFT ARTICLES, supra note 29, art. 29, at 317. Black's Law Dictionary distinguishes between the two concepts as follows: consent is "[w]illingness in fact that an act or invasion of an interest shall take place," BLACK's LAW DICTIONARY 305 (6th ed. 1990); waiver is the "intentional or voluntary relinquishment of a known right," id. at 1580. Moreover, waiver occurs when one "does or forbears to do something the doing of which or the failure of forbearance to do which is inconsistent with the right, or his intention to rely upon it." Id. 
Thus, the asylum state may opt not to press its claim and demand an appropriate remedy for the breach. In the context of international abduction, the question is whether waiver can be inferred from a failure of the asylum state to protest the abduction or to demand reparation for the violation of its sovereignty. F.A. Mann has argued that waiver must be explicit: "It is submitted that if the State does or says nothing, the illegality remains. It is impossible to infer consent from silence or inactivity.",53 Although Mann's position may represent good policy, both logic and state practice suggest that in the context of state-sponsored international abduction, waiver of the right to assert responsibility may properly be inferred from silence or inaction.

This conclusion follows from the fact that once an international wrong has been committed, the aggrieved state must assert responsibility if it desires that the delinquent state discharge its obligation. ${ }^{54}$ Thus, if a state does not act to seek redress, it would seein permissible to conclude that the state has waived its right to a remedy, even if it has not consented to the underlying wrongful act. $^{55}$ Indicative of this position is comment (c) of section 432 of the Restatement (Third) of Foreign Relations which states,

If the unauthorized action includes abduction of a person, the state from which the person was abducted may demand return of the person, and international law requires that he be returned. If the state from which the person was abducted does not demand his return, under the prevailing view the abducting state may proceed to prosecute him under its laws. ${ }^{56}$

This conclusion is also firmly supported by state practice. In the United States, for example, the Ninth Circuit, in United States $v$. Verdugo-Urquidez, held that "a nation may consent to the removal of an individual from its territory ... after the fact, by failing to protest a kidnapping. ... Because the kidnapping violates the nation's rights ... the nation may waive those rights." ${ }^{\text {"57 }}$ Addition-

53. Mann, supra note 23 , at 409 .

54. See 2 RESTATEMENT OF FOREIGN RELATIONS § 902(1) (1987) ("A state may bring a claim against another state for a violation of an international obligation . . .." (emphasis added)).

55. There is an issue of how much time must elapse before a state may conclude that the asylum state has waived its right to a remedy. This issue, however, would appear to be a question of fact for the court to evaluate in light of all the rclevant facts and circumstances, rather than a matter of international law.

56. 2 RESTATEMENT OF FOREIGN RELATIONS $\$ 432 \mathrm{cmt}$. c.

57. United States v. Verdugo-Urquidez, 939 F.2d 1341, 1352 (9th Cir. 1991) (empha- 
ally, in Matta-Ballesteros v. Henman, the Seventh Circuit held that "[w]ithout an official protest, we cannot conclude that Honduras has objected to Matta's arrest." 58 The French Cour de Cassation reasoned similarly in $R e$ Argoud..$^{59}$ In that case, Argoud, a French national, had been sentenced to death in 1961 in absentia for his participation in illegal political activities. ${ }^{60}$ In 1963, Argoud was abducted from a Munich hotel room and taken to Paris, where he was subsequently arrested. ${ }^{61}$ Argoud argued that since his abduction violated international law, he should be returned to West Germany. ${ }^{62}$ The court rejected his plea and suggested that West Germany's inaction constituted a waiver of any rights it might have as a result of the abduction. The court stated, "[E]ven accepting that Argoud had been abducted on the territory of the Federal Republic of Germany in violation of the rights of that country and of its sovereignty, it would be for the Government of the injured State alone to complain and demand reparation." 63 Israeli courts also have adopted this position, as evidenced by the holding of the supreme court in the Eichmann case that "such waiver inay be explicit or by acquiescence." ${ }^{64}$ The Canadian government also seems to support this view. In its amicus brief to the U.S. Supreme Court in the Alvarez-Machain case, it stated that in the case of an abduction from the United States to Canada, the "Government of Canada would, upon protest, cooperate to obtain the return of an abducted fugitive." ${ }^{25}$ The United Kingdom

ses added), vacated, 112 S. Ct. 2986 (1992).

58. Matta-Ballesteros v. Henman, 896 F.2d 255, 260 (7th Cir.), cert. denied, 498 U.S. 878 (1990). In United States ex rel. Lujan v. Gengler, 520 F.2d 62, 67 (2d Cir.), cert. denied, 421 U.S. 1001 (1975), the Second Circuit also stressed the importance of a protest by the asylum state. It noted that neither Argentina nor Bolivia had protested the defendant's abduction, which suggested that these countries had opted to waive their right to assert responsibility.

59. Re Argoud, 45 I.L.R. 90 (Cass. Crim. 1964) (Fr.).

60. Id. at 91 .

61. Id. at 92 .

62. Id.

63. Id. at 97. Similarly, the special court of state security had previously held, in the same case, that "[t]he individual who claims to be injured . . . lacks the right or capacity to plead in judicial proceedings a violation of international law, a fortiori when the state concerned makes no claim." Id. at 94.

64. Attorney Gen. v. Eichmann, 36 I.L.R. 277, 305 (Isr. Sup. Ct. 1962) (affirming the conclusions of the district court).

65. Brief of the Canadian Government as Amicus Curiae at 3, United States v. Alvarez-Machain, 112 S. Ct. 2188 (1992) (No. 91-712), available in LEXIS, Genfed Library, Briefs File [hereinafter Canadian Brief] (emphasis added). 
courts $^{66}$ and the Mexican government also agree on this point. ${ }^{67}$ In general, therefore, state practice supports the conclusion that if a state fails to protest an abduction from its territory, the abducting state may infer that the asylum state has waived its right to assert a claim of responsibility for the otherwise unlawful act.

\section{REMEDIES IN CASES OF INTERNATIONAL ABDUCTION}

\section{A. The Remedy of Restitutio in Integrum}

In his treatment of the law of state responsibility, Ian Brownlie has questioned whether it is appropriate to determine the proper international law remedy for any specific violation of a primary rule by relying predoiminantly on general remedial principles:

In considering issues of state responsibility, the relation between duties and forms of relief, ... is it really worthwhile to launch upon such consideration with the unargued premiss that the purpose must be the statement of generally applicable and autonomous sets of principles relating to "state responsibility," "justifications," and so on? Is it not the case that it is the nature and content of the particular duty which determines these quality of the other matters . . . ?

Brownlie thus suggests that the more logical approach is to recognize the integral relation between the specific type of wrong and the appropriate remedy. Thus, a remedy that is fully adequate and appropriate in one context and for one type of wrong may at the same time be wholly inapposite in another. Although Brownlie is

66. See, e.g., R. v. Garrett, 86 L.J.K.B. 894, 900 (1917) (emphasis added):

The men were arrested, not in violation of the law of any other country, as the foreign or neutral vessel was in a British port by agreement. No complaint was made by the neutral State or any other State concerned. These being the facts, the case of Scott, ex parte which has been alluded to, applies.

See also the opinion of the Law Officers in the Lawler case: "[W]e deem it to be a duty of the State ... to restore the aggrieved State, upon its request to that effect . . . to its original position." O'Higgins, supra note 20, at 295 (quoting Lord McNair) (emphasis added). See generally infra text accompanying notes $148-50$ for a discussion of the Lawler case.

67. Brief of the United Mexican States as Amicus Curiae at 3-5, United States v. Alvarez-Machain, 112 S. Ct. 2188 (1992) (No. 91-712) (emphasizing the Mexican government's repeated protests and demands for extradition).

68. BROWNLIE, supra note 40 , at 87 . 
certainly correct that the specific remedy should depend most directly on the specific violation, it is nonetheless important that international courts and tribunals, and many authors have stressed the general primacy of the remedy of restitutio in integrum in international law. ${ }^{69}$

In the Factory at Chorzów (Indemnity) case, the Permanent Court of International Justice declared,

The essential principle contained in the actual notion of an illegal act ... is that reparation must, as far as possible, wipe out all the consequences of the illegal act and reestablish the situation which would, in all probability, have existed if that act had not been committed. Restitution in kind, or, if this is not possible, payment of a sum corresponding to the value which a restitution in kind would bear; ... such are the principles which should serve to determine the amount of compensation due for an act contrary to international law. ${ }^{70}$

In subsequent cases, moreover, other tribunals have followed the lead of the Permanent Court of International Justice in ordering restitution when it appeared to be the most appropriate remedy of the circumstances. In the Temple case, for example, the International Court of Justice held that "Thailand is under an obligation to restore to Cambodia any objects ... . which may . . . have been removed from the Temple or the Temple area by the Thai authorities. ${ }^{\prime 71}$ In the Hostages case, ${ }^{72}$ the same court ordered the release of the United States diplomatic staff and other United States nationals held by Iran and also ordered the return of all "property, archives and documents of the United States Embassy in Tehran and of its Consulates in Iran." ${ }^{, 73}$ Further support for the primacy of this remedy can be found in the Texaco $^{74}$ case. There,

69. Support for this position is not universal however. Christine Gray, for example, writes that "[t]he few cases in which arbitration tribunals have awarded restitutio in integrum seem a weak foundation on which to build the primacy of restitutio in integrum in international law." CHRISTINE D. GRAY, JUDICIAL REMEDIES IN INTERNATIONAL LAW 16 (1987). 13).

70. Factory at Chorzów (Germany v. Pol.), 1928 P.C.I.J. (ser. A) No. 17, 1, 47 (Sept.

71. Temple of Preah Vihear (Cambodia v. Thail.), 1962 I.C.J. 6, 37 (June 15).

72. Diplomatic and Consular Staff in Tehran (U.S. v. Iran), 1980 I.C.J. 3 (May 24).

73. Il. at 45. But see GRAY, supra note 69, at 96 (stating that the Hostages case does not settle the issue of the primacy of restitution in kind in international law).

74. Texaco v. Libyan Arab Republic (U.S. v. Libya), 53 I.L.R 389 (1979) (Dupuy, Arb.). 
the arbitrator, René-Jean Dupuy, stated that the "highest doctrinal authorities favor restitutio in integrum and make it the basis of reparation, thus giving to it primacy among the various forms of reparation." 75

In addition to the judgments of tribunals, many writers also support the primacy of restitutio in integrum. Hersch Lauterpacht, for example, wrote that "the rule [is] that in international law . . . restitutio in integrum is regarded as the object of redress." 76 Others who share this view (and are quoted at length in the Texaco case) include Professor Georg Schwarzenberger, ${ }^{n}$ Eduardo Jiménez de Aréchaga, ${ }^{78}$ Professor Georges Tenekides, ${ }^{79}$ Professor Paul Guggenheim, ${ }^{80}$ and Charles de Visscher ${ }^{81}$ F.A. Mann wrote that "it seems fairly clear that ... public international law has for long recognized restitution in kind as a right, probably as the principal right, against the wrongdoing State." $\$ 22$

Although restitutio in integrum is arguably the primary international law remedy, the specific circumstances of some types of international law violations preclude the possibility of applying this remedy. First, the passage of time often makes restitution in kind difficult, if not impossible. For example, in cases in which an alien has been unjustly deprived of property, often that property has been destroyed. ${ }^{83}$ Second, restitution may not constitute an adequate remedy for all the damage suffered, especially for the moral injury suffered by the state. Third, there may be domestic legal impediments to restitution. ${ }^{84}$ While these considerations may at

75. Id. at 501-02.

76. Hersch LaUterpacht, PRivate LaW Sources and ANAlogies in INTERNATIONAL LAW 149 (1927).

77. Texaco, 53 I.L.R. at 502 (quoting 1 GeOrg SCHWARZENBERgER, INTERNATIONAL LAW AS APPLIED BY INTERNATIONAL COURTS AND TRIBUNALS 233 (1945)).

78. Id. (quoting Eduardo Jiménez de ARÉchaGa, MANUAL of Public INTERNATIONAL LaW 531, 564-67 (M. Sorenson ed., 1968)).

79. Id. at 503-04 (quoting Georges Tenekides, Responsabilité Internationale, in 2 ENCYCLOPÉdIE JURIDIQUE DALLOZ 790 (1969)).

80. Id. at 504 (quoting 2 Paul Guggenheim, Tratté de Drott International PUBL.IC 68-69 (1954)).

81. Id. at 503 (quoting Charles de Visscher, Le Déni de Justice en Droit International, 52 R.C.A.D.I. 362 , $436-37$ (1935)).

82. F.A. Mann, The Consequences of an International Wrong in International and National Law, 48 BRIT. Y.B. INT'L L. 1, 3 (1976-1977).

83. 2 F.V. Garcia-Amador, THe Changing LaW of International Claims 583 (1984).

84. See id.; L.C. Green, International Law: A Canadian Perspective § 319 (2d ed. 1988) ("Actual restoration of the status quo ante is frequently impossible and the 
times seriously inhibit the use of restitutio in integrum, they are arguably inapposite in the context of international abduction. As long as the individual is still alive, restitution is not only possible but also the most appropriate remedy to eradicate the consequences of the wrong. Moreover, to the extent that there is a moral injury to the state that is not compensated by the return of the individual, some other act of reparation in addition to returning the individual may be appropriate, but this is not a reason not to return the individual.

In conclusion, even if it is debatable whether restitutio in integrum is the primary remedy in international law, it is certainly clear that it is one accepted remedy, and arguably "first among equals. ${ }^{35}$ Moreover, returning to Browrilie's observation that obligations and remedies are mextricably linked, there is considerable state practice to support the conclusion that restitutio in integrum is the customary international law remedy in the specific context of state-sponsored international abduction. ${ }^{86}$

\section{B. Customary International Law}

Customary international law exists when "a clear and continuous habit of doing certain actions has grown up under the aegis of the conviction that these actions are, according to International Law, obligatory or right." ${ }^{37}$ There are thus two components to customary international law: a habit or practice of doing some act and a conviction that such act is legally required of the state. This latter aspect of international custom is referred to as opinio juris. $^{88}$ Evidence of state practice may come from many sources,

most common basis for measuring reparation is monetary."(footnote omitted)).

85. Brownlie, for example, writes that "[t]he conclusion justified by the evidence is that whilst it is safe to assume that specific restitution as a form of redress has a significant place in the law, it is difficult to state the conditions of its application with any certainty." BROWNLIE, supra note 40 , at 222.

86. See infra Part III.

87. OPPENHEIM, supra note 36 , at 26. See generally BROWNLIE, supra note 31 , at 4-11 (discussing the elements of international custom). According to the Restatement, "Customary international law results from a general and consistent practice of states followed by them from a sense of legal obligation." 1 RESTATEMENT (THIRD) OF FOREIGN RELATIONS $\S 102(2)$ (1987).

88. As explained in the Restatement, "[F]or a practice of states to become a rule of customary international law it must appear that the states follow the practice from a sense of legal obligation." 1 Restatement (ThIRD) OF FOREIGN RELATIONS $\S 102 \mathrm{cmt}$. c (1987). 
including "diplomatic acts and instructions as well as public measures and other governmental acts and official statements of policy, whether they are unilateral or undertaken in cooperation with other states." ${ }^{\circ 9}$ Judicial opinions of national or inunicipal tribunals also may be considered evidence of state practice. "The practice of states ... embraces not only their external conduct with each other, but is also evidenced by such internal matters as their domestic legislation, judicial decisions, diplomatic despatches, internal government memoranda and ininisterial statements in Parliaments and elsewhere." $" 90$

As will be shown, the history of state practice in cases of state-sponsored international abduction indicates that states have nearly always demanded the return of an individual improperly taken froin their territory. ${ }^{91}$ Moreover, asylum states have generally expressed their demands for return as obligations of the abducting state. Finally, in most cases, though certainly not all, the abducting state has complied with the asylum state's demand. This consistent pattern therefore supports a conclusion that an international custoin has developed in cases of state-sponsored international abduction: when an asylum state protests an abduction and demands the return of an individual taken from its territory, the abducting state is under an international legal duty to return the individual to the asylum state.

This consistent pattern of return notwithstanding, there have been incidents when the asylum state's demand for repatriation was not honored even though the facts clearly showed that the abducting state had violated international law. The most blatant example of this was the Alvarez-Machain case, the facts of which began this Note. ${ }^{22}$ Such examples, however, do not indicate that

89. 1 id. cmt. b.

90. 1 OPPENHEIM'S INTERNATIONAL LAW 26 (Sir Robert Jennings \& Sir Arthur Watts eds., 9th ed. 1992); see also 1 RESTATEMENT (THIRD) OF FOREIGN RELATIONS \& 103; BROWNLIE, supra note 31 , at 5 (noting that evidence of international custom includes "diplomatic correspondence, ... opinions of official legal advisors, ... and national judicial decisions ....").

91. See infra Part III.

92. See supra text accompanying notes 1-4. Another incident occurred in 1935 when a German national was attacked on a frontier platform in Czechoslovakia and dragged across the border into Germany. Although Czechoslovakia immediately demanded his return, it does not appear that Germany complied with the request. Preuss, supra note 21, at 504. A third example involved the abduction of several Korean students from Germany. See infra note 162 . Although Germany demanded that they be returned, apparently South Korea did not comply with the demand. Thomas H. Sponsler, International Kill- 
there is no customary law requiring return in cases of international abduction. International custom does not require that state practice be unanimous in order to acquire the force of law; some exceptions are allowed provided they are regarded as breaches of the general rule. The International Court of Justice has written,

In order to deduce the existence of customary rules, the Court deems it sufficient that the conduct of States should, in general, be consistent with such rules, and that instances of State conduct inconsistent with a given rule should generally have been treated as breaches of that rule, not as indications of the recognition of a new rule. ${ }^{93}$

Certainly the outrage engendered by the abduction of Dr. AlvarezMachain by the United States shows that the "no abduction" rule is well established and that the failure to return the individual by the United States was not accepted as a harbinger of an emerging rule permitting such action. ${ }^{94}$ Canada took the highly unusual step of filing an amicus curiae brief arguing in favor of repatriation in the Alvarez-Machain case. Further, the members of the Organization of American States requested a legal opinion from the InterAmerican Juridical Committee on the legal aspects of Dr. AlvarezMachain's abduction. The significant number of cases that have resulted in return suggests that in the instances in which the individual has not been returned, the abducting state has thereby committed a further violation of international law. As Mann writes, "[T]he failure to comply with a request for the return of the abducted person is a separate wrong which is quite independent of the original one." 95

napping, 5 INT'L LAW. 27, 42-43 (1971).

93. Military and Paramilitary Activities (Nicar. v. U.S.), 1986 I.C.J. 98 (June 27).

94. For example, in 1992, several Latin American countries and two European states favored requesting an advisory opinion from the International Court of Justice on the very issue raised by United States actions in the Alvarez-Machain case. Angulo \& Reardon, supra note 4, at 284. Further, "[a]s a State Department spokesperson acknowledged following the decision, 'Many governments have expressed outrage that the United States believes it has the right to decide unilaterally to enter their territory and abduct one of their nationals." " David O. Stewart, The Price of Vengeance, A.B.A. J., Nov. 1992 , at 50 .

95. Mann, supra note 23 , at 411. 


\section{RESTITUTIO IN INTEGRUM IN CASES OF STATE-SPONSORED ABDUCTION}

\section{A. Restitutio in Integrum and State Practice}

Although neither are authoritative sources of international custom, both the Harvard Draft Convention on Jurisdiction with Respect to Crime and the Restatement (Third) of Foreign Relations support the position that the return of the individual is the appropriate remedy in cases of state-sponsored international abduction. The commentary to article 16 of the Harvard Convention states,

It is everywhere agreed, of course, that "recourse to measures in violation of international law or international convention" in obtaining custody of a person charged with crime entails an international responsibility which must be discharged by the release or restoration of the person taken, indemnification of the injured State, or otherwise. .6

Similarly, the Restatement states that in cases of international abduction, "the state from which the person was abducted may demand return of the person, and international law requires that he be returned."97 The cases discussed below support the legal conclusion of both the Restatement and the Harvard Convention. When a person has been abducted from, or arrested in, the territory of another state by officials or agents of the abducting state, the asylum state has not consented to the arrest, and the asylum state has demanded the return of that individual, the abducting state usually has returned the individual. For the purposes of showing opinio juris, moreover, the demand for return is as important as the actual return of the individual, as that demand indi-

96. Draft Convention on Jurisdiction with Respect to Crime, 29 AM. J. INT'L L. 437, 623-24 (1935). The following sentence, however, severely limits the "of course" nature of the asserted remedy: "It is not everywhere agreed that there may be no prosecution or punishment in reliance upon custody thus obtained 'without first obtaining the consent of the State or States whose rights have been violated by such measures.' " Id. at 624. This distinction suggests that the remedy of return was not at the time of the Harvard Convention nearly as accepted as the commentary at first intimates. This conclusion is reinforced by the fact that the drafters of the Convention explicitly acknowledged that article 16 was "in part of the nature of legislation." Id. Nonetheless, the drafters opined that this remedy was desirable due to the "most persuasive considerations of policy." Id. at 623.

97. 1 RESTATEMENT (THIRD) OF FOREIGN RELATIONS $\S 432 \mathrm{cmt}$. c (1987). 
cates the asylum state's belief that return is the appropriate remedy.

1. United States. A review of United States practice over the past 150 years indicates that the executive branch of the U.S. government has been a consistent proponent of the position that in cases of abduction or extraterritorial arrest in violation of a nation's territorial sovereignty, the arresting state is obligated to return the individual. ${ }^{98}$ Moreover, evidence of United States practice reflects opinio juris and refutes the position that this practice has been merely an issue of comity. Specifically, the official correspondences of the U.S. government have stressed that the remedy of return is an international legal right. The following incidents present only a limited sample of the numerous times in which the United States has either demanded the return of an individual abducted from U.S. territory or returned an individual abducted from another state's territory; other instances abound.9 ${ }^{99}$

The Nogales case of $1887^{100}$ presented an explicit endorse-

98. In virtually every instance in which the United States has failed to return an abducted individual, there was arguably no breach of international law. See United States v. Reed, 639 F.2d 896 (2d Cir. 1981) (no demand for return by the Bahamas); United States v. Lara, 539 F.2d 495 (5th Cir. 1976) (noting involvement of national police in arrest); United States ex rel. Lujan v. Gengler, 510 F.2d 62 (2d Cir.) (same), cert. denied, 421 U.S. 1001 (1975); United States v. Herrera, 504 F.2d 859 (5th Cir. 1974) (same); United States v. Toscanino, 500 F.2d 267 (2d Cir. 1974) (no demand for return by Uruguay); United States v. Cotten, 471 F.2d 744 (9th Cir.) (noting involvement of local police in arrest), cert. denied, 411 U.S. 936 (1973); United States v. Unverzagt, 299 F. 1015, 1017 (W.D. Wash. 1924) (no demand for return by Canada), aff'd sub nom. Unverzagt v. Benn, 5 F.2d 492 (9th Cir.), cert. denied, 269 U.S. 566 (1925); State v. Brewster, 7 Vt. 118 (1835) (same).

- 99. See 2 Green H. Hackworth, Digest of international law 310-11 (1941). Hackworth recounts the Cantu incident of 1914. In that case, the former mayor of Lampasos, Mexico, was seized in the United States and dragged across the border into Mexico. The United States demanded his immediate release and return. Four days later, Cantu was released. See also 4 JOHN B. MOORE, A Digest OF INTERNATIONAL LAW $\S 603$ (1906) [hereinafter MOORE's DIGEST] (noting incident in which the demand by the United States for the return of Rufino Rueda, who, on June 19,1891, was abducted from Key West and taken to Havana by Spanish agents, was complied with); C.V. Cole, Extradition Treaties Abound, but Unlawful Seizures Continue, INT'L PERSPECTIVES, Mar.Apr. 1975, at 40-41 (reciting a 1908 incident involving Adeland Lefond, who was arrested in Illinois, taken to Canada, and held in a Winnipeg jail; upon "the request of the U.S. consul, LeFond was released . . . and he was provided with free transportation back to Illinois"); id. at 41 (noting a 1909 incident in which a Mr. Marker was arrested in the United States by two men, one of whom claimed to be a member of the North West Mounted Police; after a protest by the United States, Marker was released).

100. 1 JohN B. MOORE, A TREATISE ON EXTRADITION \& INTERSTATE RENDITION 
ment by the United States of the legal obligation to return an abducted individual. In that case, a Mexican lieutenant was arrested in Arizona for assaulting a constable. In transit to the prison, the lieutenant was rescued by several Mexican soldiers and escaped with them to Mexico. ${ }^{101}$ The U.S. government immediately demanded that the Mexican lieutenant be returned to the United States, and on the next day Mexico agreed to do so. After the agreement to return the lieutenant, confusion arose because Mexico believed that the United States had offered the choice either to return the individual to the United States or to punish the lieutenant in Mexico. To clear up this misunderstanding, the United States stated, in no uncertain terms, that "the armed invasion ... left for Mexico the simple international duty of restoring him to the place from which he was taken." 102

A similar demand was made by the United States in the case of Abraham Gonzales. Gonzales was kidnapped from the United States by a Mexican military officer. The United States immediately wrote to the American legation in Mexico, "You will lose no time in making a representation upon this subject to the Mexican government. You will demand the return of Gonzales ...."103 Another incident arose in 1849, when the United States demanded the return of a Cuban political refugee who had been kidnapped from New Orleans under direction of the Spanish consul. The U.S. consul in Havana was instructed to "demand . . . the prompt surrender of the person in question, in order that he might be sent back to New Orleans." 104

Another incident was the case of Grogan. ${ }^{105}$ In 1841, British soldiers seized this American citizen from his house in Vermont and took him to to Canada. Acting Secretary of State Webster wrote the British minister and demanded the release and restoration of Grogan. In response, the British minister immediately ordered the acting governor of Canada to release Grogan, who was

\footnotetext{
$\S 196$ (1891) [hereinafter MOORE'S TREATISE].

101. 1 id.

102. 1 id. (emphasis added).

103. Letter from Mr. W. Hunter to Mr. Thomas H. Nelson (Aug. 1, 1872), in 1 U.S.

DEP'T OF STATE, Foreign Relations OF THE UNITEd STATES 448 (1872).

104. See 4 MOORE'S DIGEST, supra note 99, \& 603.

105. 1 MOORE'S TREATISE, supra note 100, \$ 189.
} 
then escorted back to Vermont. ${ }^{106}$ In the case of Blair, ${ }^{107}$ an 1876 incident, an individual posing as a British member of Parliament kidnapped an American citizen and took him to the United Kingdom. The United States wrote to the United Kingdom and requested that "the man be immediately set at liberty and restored to this country."108 Notwithstanding the fact that Blair had already been convicted in England on a criminal charge, he was released and returned to the United States. ${ }^{109}$

In March 1911, two U.S. citizens, Edward M. Blatt and Lawrence F. Converse, were abducted in the United States by Mexican citizens and conveyed across the Rio Grande into Mexico. ${ }^{110}$ Once in Mexican territory, they were arrested on a charge of sedition by Mexican soldiers who were awaiting their arrival and who had been directing the kidnappers. In response, the U.S. government wrote to the Mexican government that these actions constituted a "grave violation of the sovereignty of the United States"111 and that the U.S. government "would be obliged to request that they be immediately returned."112 Mexico subsequently released the two men.

Incidents in which the United States has acknowledged return to be the proper international law remedy have also occurred when the United States was the abducting party. In the case of Bratton, ${ }^{113}$ in 1872, the British government complained to the United States that Dr. Rufus Bratton had been seized in Canada and taken to the United States, where he was arrested for violation of the $\mathrm{Ku}$ Klux Act. The British government communicated to the U.S. government that it considered the act to be a violation of British sovereignty and territorial independence and requested

106. 1 id.

107. 1 id. § 191.

108. 1 id.

109. 1 id.

110. 2 HACKWORTH, supra note 99 , at 309.

111. 2 id. (quoting note from acting Secretary of State Wilson to the Mexican Ambassador de la Barra (Mar. 14, 1911)).

I12. $2 \mathrm{id}$. It is interesting to note that the U.S. government also argued, in the alternative, that even if the two individuals had been apprehended in Mexican territory, they had subsequently been transported over United States territory before reentering Mexico. The U.S. government argued that this violation of American sovereignty alone would be sufficient to warrant the release of Blatt and Converse. 2 id. at 309-10.

113. 1 MOORE'S TREATISE, supra note $100, \S 190$. 
the return of Bratton. ${ }^{114}$ The U.S. Secretary of State, Hamilton Fish, replied,

When the matter of Bratton's abduction was first brought to the attention of this government ... prompt and immediate steps were at once taken to have him returned to the authorities and jurisdiction of Canada. I trust that I need not assure you that the government of the United States would lend no sanction to any act of its officers or its citizens involving a violation of the territorial independence or sovereignty of her Majesty's dominions. ${ }^{115}$

Another incident arose in 1920, when U.S. officers arrested a U.S. citizen, Vincenti, while in British territorial waters. ${ }^{116}$ Soon thereafter, the Department of State informed the ambassador of the United Kingdom that Vincenti's bail had been dismissed and that all proceedings subsequent to his "unlawful arrest" had been dropped. ${ }^{117}$ A final incident is the case of Ronald J. Anderson, who, on August 24, 1974, was crossing into the United States from Canada. ${ }^{18}$ When Anderson was recognized by the customs officer as an army deserter, he fled back over to the Canadian side of the border. United States officials pursued Anderson into Canada, arrested him there, and removed him to the United States. The Canadian governinent protested the arrest and Anderson was returned to Canada. ${ }^{119}$

In addition to United States diplomatic practice, U.S. court decisions also have acknowledged that the return of the individual is the proper remedy for international abductions, even if they have not recognized any power of their own to effectuate the return. ${ }^{120}$ For example, in United States $v$. Insull, ${ }^{121}$ a case in which the defendant was forcibly removed from a Greek ship by Turkish police officers, the district court held that "[t]he Hellenic Republic or Turkey, through their sovereignties, if unlawfully in-

114. 1 id.

115. 1 id. (quoting Letter from Mr. Fish, Secretary of State, to Sir E. Thornton (Nov. $12,1872)$ )

116. 1 Green H. HaCKWORTh, Digest of INTERNATIONAl LAW 624 (1940).

117. 1 id.

118. Cole, supra note 99 , at 42.

119. Id.

120. See infra Part IV.

121. 8 F. Supp. 310 (N.D. Ill. 1934). 
vaded, may demand reparation and a surrender of the abducted party ....."122

2. Canada. As one might infer from the above discussion of U.S. practice, Canadian practice also has supported the development of the customary international law norm. In the Lefond case $^{123}$ and the Marker case, ${ }^{124}$ the Canadian government returned individuals who had been abducted from, or arrested in, the territory of the United States, and in the Anderson case, ${ }^{125}$ the Canadian government demanded the return of an individual who had been improperly taken from its territory.

Two further imcidents also reflect the Canadian government's position on the issue. The first occurred in 1863, when two Canadian constables abducted two individuals from the United States. When the United States protested the arrest in its territory, the "governor general of Canada ... offered at once to restore the abducted persons, if the United States should require it." 226 In a letter sent to the British government, Lord Monck, governor of Canada, wrote that "[i]nasmuch, however, as [the abductees] were made amenable [to Canadian judicial power] by an act clearly illegal on the part of the Canadian constables, I am prepared to restore them .... to the custody from which they were removed ...." The second incident occurred in 1960. In that case, two American Indians, Edward and Howard Kohosed, were removed from a workboat on the St. Clair river by Michigan police. The Canadian government argued that the arrest took place in Canadian waters and that "in light of the circumstances of the arrest, the two men should have been released and immediately returned to Canada." 128

122. Id. at 313; see also United States v. Unverzagt, 299 F. 1015, 1016-17 (W.D. Wash. 1924) (noting that in the case of a person abducted from British Columbia, either England or Canada could demand return, but that this was a political matter between sovereigns), aff'd sub nom. Unverzagt v. Benn, 5 F.2d 492 (9th Cir.), cert. denied, 269 U.S. 566 (1925). Cf. United States v. Toscanino, 500 F.2d 267, 278 (2d Cir. 1974) (noting that abductions that violate a nation's sovereignty are generally redressed by returning the individual).

123. See supra note 99.

124. Id.

125. See supra text accompanying notes 118-19.

126. 4 MOORE's DIGEST, supra note $99, \S 603$.

127. Letter from Lord Monck to Lord Lyons (May 22, 1863), supra note 36, at 622.

128. Cole, supra note 99, at 41. 
The most explicit evidence of the Canadian position on international abduction, however, is set forth in its amicus curiae brief to the U.S. Supreme Court in the case of United States v. AlvarezMachain. ${ }^{129}$ In its brief, the Canadian government stated that

Canada and its component governments do not hold to a policy of abductions from American territory, and if abductions occur, they could not reasonably expect the United States to acquiesce in Canadian courts' disrespect of U.S. sovereignty through exercise of jurisdiction over abducted individuals. The Government of Canada would, upon protest, cooperate to obtain the return of an abducted fugitive. ${ }^{130}$

The brief continued that in Canada's view, the "customs and usages of civilized nations ... suggest that official abductions are unlawful and require restitution of the status quo ante."131 The fact that Canada also argued that state-sponsored abductions would violate the extradition treaty in force between the United States and Canada ${ }^{132}$ could lessen the persuasive force of the quoted statements. However, the Canadian argument seemed to be based on the theory that such abductions would violate both Canadian sovereignty generally and the extradition treaty specifically, ${ }^{133}$ indeed, in its brief the Canadian government explicitly relied on a survey of foreign governments to support its position that statesponsored abduction violates international law and requires the return of the individual. Many of the responding governments, moreover, maintained that an abduction would constitute a violation of their sovereignty regardless of any collateral violation of a bilateral extradition treaty. ${ }^{134}$ Because Canada supported its position by relying on the statements of nations that would protest and demand return even without the existence of an extradition treaty with the abducting state, it is difficult to argue that Canada's position rested exclusively on the breach of the extradition treaty.

129. 112 S. Ct. 2188 (1992).

130. Canadian Brief, supra note 65 , at 3 .

131. Id. at 4 .

132. Id.

133. Id. ("Canada sets forth a survey of some of the incidents and expressions of policy which show the understanding in international law that abducted persons must be returned to a nation when it protests the infringement of its sovereignty." (emphasis added)).

134. See infra text accompanying notes 170-73. 
3. Mexico. With one exception, ${ }^{135}$ Mexico's conduct in international abduction cases also has contributed to the development of the international custom requiring return. Mexican demands for the return of individuals have met with only limited success: in the Martinez incident, ${ }^{136}$ Ex parte Lopez, ${ }^{137}$ and the Alvarez-Machain case, the Mexican government's demands did not result in return of the abducted individuals. ${ }^{138}$ Nonetheless, the constant demands for return are testament to the Mexican government's position that repatriation is the appropriate remedy for an unlawful abduction. Moreover, Mexico's position in the Nogales ${ }^{139}$ incident was particularly clear in this respect. In that case, in response to the demand by the United States for the return of the lieutenant, the Mexican minister of foreign affairs "admitted the right of the United States to demand the restoration of the status quo."140 In addition, like Canada and the United States, Mexico has repatriated persons abducted in violation of international law. ${ }^{141}$

4. The United Kingdom. British practice also lends support to the conclusion that customary international law requires the

135. In an 1881 incident, although Mexico protested an abduction from Mexico by a U.S. sheriff and demanded that the abductor be punished, Mexico did not demand return of the individual. Letter from Señor de Zamacona to Mr. James G. Blaine (Aug. 8, 1881), in U.S. DeP'T OF STATE, ForeIgN RELATIONS OF THE UNITED STATES 837-38 (1881). Although there was one other incident in which Mexico did not demand return, that failure can be explained by the fact that the incident generated such outrage that the U.S. judge set the abductee free the day after he was sentenced and therefore Mexico had no reason to demand his return. Letter from Señor M. Romero to Mr. W.Q. Gresham (Sept. 6, 1893), in U.S. DEP'T OF STATE, FOREIGN RELATIONS OF THE UNITED STATES 457 (1893).

136. See infra note 138 .

137. 6 F. Supp. 342 (S.D. Tex. 1934).

138. The failure to return the individual is justified in two of these cases since no violation of international law appears to have occurred. In the Martinez incident, the abduction was apparently committed by private individuals and thus there was no state act that could give rise to responsibility. See Letter from the Acting Secretary of State to the Mexican Chargé (June 22, 1906), in 2 U.S. DEP'T OF STATE, supra note 40, at 1121-22. In Ex parte Lopez, 6 F. Supp. at 344, although two of the abductors were U.S. agents, another was a captain in the Mexican army. This involvement constituted consent and destroyed any claim of state responsibility.

139. See text accompanying notes 100-102.

140. 1 MOORE'S TREATISE, supra note $100, \S 196$ (emphasis added).

141. See supra text accompanying notes 110-12. 
return of an abducted individual. In the Grogan case, ${ }^{142}$ the British minister ordered the acting governor of Canada to restore a person taken from the United States, and in the Bratton case, ${ }^{143}$ the United Kingdom demanded the return of an abducted individual. An 1861 correspondence from the United Kingdom to the United States involving the arrest by the American Navy of four British subjects from the inerchant vessel Trent is instructive:

[I]t thus appears that certain individuals have been forcibly taken from on board a British vessel, ... an act of violence which was ... a violation of international law .... Her Majesty's Government trust that ... The Government of the United States ... will ... offer to the British Government such redress as alone could satisfy the British nation, namely, the liberation of the 4 prisoners taken from the Trent, and their delivery to your Lordship . . . . ${ }^{144}$

This position was reiterated in 1863, when the British government wrote to the United States with respect to an incident involving Ebenezor Tyler, who was taken from his house in the township of Wolf Island, Canada, by U.S. soldiers. ${ }^{145}$ In response to the incident, Lord Lyons wrote to William Seward, the U.S. Secretary of State, "I do not doubt that, if the statenients made in the enclosed docunients be not disproved, the governinent of the United States will at once set Tyler at liberty, and offer to her Majesty's government due satisfaction for the violation of her Majesty's territory."146 The United States replied that assuming the facts to be as stated, "you correctly appreciate the sense of justice of this government by expecting that Tyler will be set at liberty, and that other proper reparation will be made to her Majesty's government."147

Most explicitly, the Law Officers specifically endorsed this reniedy in the Lawler case of 1860 . In that case, Lawler, a convict, had escaped from Gibraltar and fled into Spanish territory, where

142. See supra text accompanying note 105 .

143. See supra text accompanying notes 113-15.

144. Letter from Mr. William H. Seward to Lord Lyons (Dec. 26, 1861), in 55 BRITISH AND FOREIGN STATE PAPERS 627, 627-28 (1864-1865) (emphasis added).

145. Letter from Lord Lyons to Mr. William H. Seward (Mar. 19, 1863), in 1 U.S. DEP'T OF STATE, supra note 36 , at 524 .

146. Id.

147. Letter from Mr. William H. Seward to Lord Lyons (Mar. 20, 1863), in 1 U.S. DEP'T OF STATE, supra note 36 , at 525 . 
he was apprehended by a British prison officer. ${ }^{148}$ The Law Officers wrote that "[a] plain breach of international law having occurred, we deem it to be the duty of the State, into whose territory the individual ... was conveyed, to restore the aggrieved State, upon its request to that effect, as far as possible, to its original position." 149 They thus advised "that notice be given to the Spanish authorities that, at a given time and place . . L Lawler will be set at liberty." $" 150$

5. European States. Evidence of the customary international law requiring the return of the abducted individual is also found in the practice of several other European states during the last 125 years.

In 1873, Lorenzo Caratacciolo, an Italian refugee residing in Corfu, was induced to board an Italian steamer in port in Corfu. ${ }^{151}$ Once on board, Caratacciolo was put in irons by Italian officers, and the steamer soon left port. When the Greek government demanded that Italy restore Caratacciolo to Corfu, Italy refused. In a conversation with a member of the United States legation in Athens, Mr. Delegeorges, the Greek minister, stated in exasperation that "[t]his transaction only proves that small powers have no rights." 152 In a subsequent letter from the United States legation, the U.S. ambassador further developed the Greek position. He stated,

I am informed that the Greek prime minister, Mr. Delegeorges, has demanded of the Italian government the restoration of the deported refugee to his home at Corfu, and that proper reparation be made by it "for," to quote the language of the Nomarch [sic] of Corfu, "the insult offered to the sovereign rights of Greece."153

148. O'Higgins, supra note 20, at 295.

149. Id. (emphasis added).

150. Id. Further evidence of United Kingdom practice is found in one 1892 incident in which the British government agreed to return to New York a boy who had been abducted from that state. 4 MOORE's DIGEST, supra note $99, \S 603$.

151. Letter from Mr. John M. Francis to Mr. Hamilton Fish (Feb. 10, 1873), in 1 U.S. DEP'T OF STATE, Foreign Relations of THE UNITED STATES 432, 432-33 (1873).

152. $1 \mathrm{id}$. (emphasis added). The language of the minister indicates that the Greek government believed return was a matter of right, not of comity. In other words, the Greek government evidently believed that its rights were not being respected by Italy's refusal to release Caratacciolo after Greece had demanded his return.

153. Letter from Mr. John M. Francis to Mr. Hamilton Fish (Feb. 13, 1873), in 1 U.S. 
The Italian court's handling of this incident also deserves to be highlighted, as its actions are further evidence of the international custom requiring repatriation. The U.S. ambassador reported that "the Court of appeals at Trani, in [Italy], promptly decided that the arrest of Caratacciolo was in violation of international law, and granted him liberty on the condition that he should leave Italy within five days." 154

In 1933, Jacob Solomon, a German political émigré living in Switzerland, was induced to enter into a car that was then driven through the Swiss customs post and into German territory. ${ }^{155}$ Once in Germany, officials awaiting his arrival arrested him. The Swiss government protested this "grave violation of [its] sovereignty" and demanded his immediate return. ${ }^{156}$ Although the German governınent initially refused to surrender Solomon, ${ }^{157}$ it soon "admitted error and returned Jacob[] to Swiss authorities.",158

The case In re Jolis ${ }^{159}$ is also reflective of this general pattern. On July 9, 1933, Pierre Jolis, a Belgian national, visited a café in France. After Jolis left the café and returned to Belgium, the proprietor of the café noticed that some money was missing. The proprietor and two French gardes-champetres proceeded to enter Belgian territory, arrest Jolis, and return him to France. The Belgian government lodged an official protest with the French government and demanded the return of Jolis. When the case came before the French court, it held that " $[t]$ he arrest, effected by French officers on foreign territory, could have no legal effect whatsoever, and was coinpletely null and void."160 The court proceeded to order that Jolis be released. ${ }^{161}$

Although the following cases are not explicit endorsements of the requirements of international law, the actions of the parties, including the demand for return, constitute some evidence of the

DEP'T OF STATE, supra note 151, at 435 (emphasis added).

154. Letter from Mr. John M. Francis to Mr. Hamilton Fish (Mar. 1, 1873), in 1 U.S.

DEP'T OF STATE, supra note 151, at 437.

155. Preuss, supra note 21 , at 503.

156. Id.

157. The German government claimed that the abduction was not committed by government officials and thus that there had been no international wrong committed by the German government. Id.

158. BASSIOUNI, supra note 13 , at 235.

159. 7 Ann. Dig. 191 (Trib. Correctionel d'Avesnes 1933) (Fr.).

160. Id.

161. Id. at 192. 
international custom. ${ }^{162}$ In 1885 , agents of Baden, Germany, apprehended a fugitive in Swiss territory. In response to the request of the Swiss government, the German authorities ordered his release. ${ }^{163}$ The Italian government took similar action the following year after Italian agents arrested an Italian national in Swiss territory ${ }^{164}$ In another case, Mr. Gutzeut, a German national, was abducted from Dutch territory and taken to Germany. The Dutch government demanded his return, and soon thereafter German authorities conducted Gutzeut to the border. ${ }^{165}$ In a more recent case, the Dutch government demanded the "immediate return" of a criminal defendant who had been lured to Germany by undercover agents. The highest German court with jurisdiction in criminal and civil cases recognized that the Dutch government had a right to "restitution," which may have to take the form of the physical return of the individual. ${ }^{166}$

Finally, many countries that have not been included in this review of specific instances of abduction have nonetheless expressed their views on the consequences of an international abduction. In response to the kidnapping of Sidney Jaffe from Canada by two United States bounty hunters in $1981,{ }^{167}$ Canada requested from foreign governments their opinions as to the propriety of international abductions. ${ }^{168}$ A similar survey was conducted in 1992, in reaction to the abduction of Alvarez-Machain. ${ }^{169}$ In its amicus curiae brief in the Alvarez-Machain ${ }^{170}$ case, the Canadian government related the views of the survey respondents. Australia, Austria, Finland, Germany, Great Britain, the Netherlands, Nor-

I62. In addition to the cases recounted here, see Mann, supra note 23 , at 411,411 n.20. An interesting, though somewhat inconclusive, incident occurred in 1967. From June 16 to June 20 of that year, a total of 24 South Korean students were removed from various countries (fourteen were taken from Germany, eight from France, one from the United States, and one from Australia). Sponsler, supra note 92, at 42 . Once in South Korea, the students were charged with involvement in a large scale communist espionage network. Id. at 42-43. Two of the aggrieved states, Germany and France, demanded the return of the students. Id. South Korea apologized to France and stated that the students would be permitted to return to France. Id.

163. Preuss, supra note 21 , at 506 .

164. Id.

165. Id. at 505 n.13.

166. Judgment of Dec. 19, 1986, BGH, 1987 NJW 3087.

167. See Lewis, supra note 20 , at 345 .

168. Canadian Brief, supra note 65 , at 5 .

169. Id.

170. United States v. Alvarez-Machain, 112 S. Ct. 2188 (1992). 
way, New Zealand, Sweden, and Switzerland all "indicated that they would regard such an abduction as a violation of their sovereignty and would protest."'171 Finland, Germany, Great Britain, and the Netherlands stated that they would demand the return of the abducted person. ${ }^{172}$ In addition, Austria, Finland, the Netherlands, Norway, Sweden, and Switzerland said that if an abducted person were brought to their territory, they "would consider that the ... person should be returned"173 to the asylum state.

\section{B. Conclusions on State Practice}

In addition to the conclusion that state practice supports the return of an abducted individual when the asylum state protests the abduction, two other conclusions can be drawn from this review of state practice. The first is that the nationality of the abducted person is irrelevant as to both the nature of the violation and the duty of the abducting state to return the individual. State practice strongly suggests that states perceive the underlying wrong to be the violation of territorial sovereignty; states have protested and demanded return regardless of the nationality of the abducted individual. For example, the United States protested the abduction of Cantu and Nogales, both Mexican nationals; ${ }^{174}$ Canada protested the arrest of Anderson, a United States national; ${ }^{175}$ Switzerland protested the abduction of Jacob Solomon, a German émigré, ${ }^{176}$ Greece protested the abduction of Caratacciolo, an Italian refugee, ${ }^{177}$ and Germany and France both protested the abduction of South Korean students. ${ }^{178}$

A more tentative conclusion is that the purpose of the abduction also is irrelevant. Although only two cases are on point, in both cases when a person has been "retaken" from the asylum state, the asylum state has nonetheless protested. Thus, in the An-

171. Canadian Brief, supra note 65 , at 5 .

172. Id. Of these countries, only Great Britain stated that it would consider the abduction to constitute, in addition, a violation of a bilateral extradition treaty. Id. Thus, most countries considered return to be the appropriate remedy for the violation of their sovereignty, regardless of any collateral violation of a bilateral extradition treaty.

173. Id.

174. See supra note 99, text accompanying notes 100-02.

175. See supra text accompanying notes 118-19.

176. See supra text accompanying notes 155-58.

177. See supra text accompanying notes 151-54.

178. See supra note 162 . 
derson case, Canada demanded that the United States restore the individual even though he had only moments before fled from the United States into Canada. ${ }^{179}$ Similarly, in the Lawler case, the Law Officers did not consider it important that the individual had escaped from British territory. ${ }^{180}$ This position, moreover, is logically consistent with the view that the underlying wrong is the violation of the territorial sovereignty of the asylum state; the purpose of the abduction does not, and should not, affect the nature of the wrong.

\section{PROBLEMS OF EFFECTUATING RETURN: THE UNITED STATES}

The preceding discussion indicates that the customary international law remedy is well established in cases of state-sponsored international abduction. Nonetheless, the issue remains in the United States and other countries ${ }^{181}$ as to whether domestic courts have the power to effectuate this international law remedy.

As a general matter, international law is part of United States law, though the extent to which it is relied on by domestic courts and the extent to which domestic courts are empowered to effectuate it is subject to much debate. ${ }^{182}$ The Constitution states that treaties "shall be the suprenie Law of the Land,"183 and although customary international law is not similarly mentioned in the Constitution, some have argued that it should be equally enforceable. ${ }^{184}$ The Restatement (Third) of Foreign Relations asserts that international law is part of United States law and states that "[i]nternational law and international agreements of the United States are law of the United States and supreme over the law of the several States." 185

179. See supra text accompanying notes $118-19$.

180. See supra text accompanying notes 148-50.

181. For example, it appears that the German Constitutional Court does not consider ordering the return of an abducted person to be within its power. See Mann, supra note 23, at 421 n.72.

182. See Lea Brilmayer, International Law in American Courts: A Modest Proposal, 100 YALE LJ. 2277, 2283-91 (1991).

183. U.S. CONST, art. VI, cl. 2.

184. Louis Henkin, International Law as Law in the United States, 82 MiCH. L. REV. 1555, 1564-67 (1984).

185. 1 RESTATEMENT (THIRD) OF FOREIGN RELATIONS $\S 111(1)$ (1987). 
Notwithstanding this general rule, United States courts hearing international abduction cases have held that it is beyond their power to order the return of an individual seized in violation of international law. They have held that if an individual is to be repatriated, such repatriation must be effectuated by the executive branch. ${ }^{186}$ Arguably, however, United States courts have misconstrued their own power in reaching this conclusion.

The question of the proper remedy in cases of international abduction first arose in a United States court in State $v$. Brewster. ${ }^{187}$ In that case, "citizens"188 of Vermont apprehended the defendant from Canada and returned him to the state to stand trial on a charge of burglary. ${ }^{189}$ The Supreme Court of Vermont held that "[t]he illegality, if any, consists in a violation of the sovereignty of an independent nation. If that nation complain, it is a matter which concerns the political relations of the two countries, and in that aspect, is a subject not within the constitutional powers of this court."190 When presented with similar instances of international abduction, federal courts also generally have adopted a limited view of their power. In United States $v$. Unverzagt ${ }^{191}$ for example, the district court held that "[a]ny infractions are subject to international negotiation, so far as the party chooses to seek redress. It must be obvious that with this the courts have nothing to do." ${ }^{192}$ Similarly, in United States v. Insull, ${ }^{193}$ the district court held that "the mere fact ... that [the defendant] was kidnapped from the Hellenic authorities, would not give this court power to

186. See, e.g., United States v. Sobell, 142 F. Supp. 515, 523 (S.D.N.Y. 1956) ("The question of violation of international law . . . is to be left to the proper consideration of the political and executive branches of the government should the offended state choose to raise the issue."), aff'd, 244 F.2d 520 (2d Cir.), cert. denied, 355 U.S. 873 (1957); United States v. Insull, 8 F. Supp. 310 (N.D. Ill. 1934); United States v. Unverzagt, 299 F. 1015 (W.D. Wash. 1924), aff'd sub nom. Unverzagt v. Benn, 5 F.2d 492 (9th Cir.), cert. denied, 269 U.S. 566 (1925); State v. Brewster, 7 Vt. 118, 122-23 (1835); cf. United States v. Alvarez-Machain, 112 S. Ct. 2188, 2196 n.16 (1992) (noting the "advantage of the diplomatic approach").

187. 7 Vt. 118 (1835).

188. The facts do not indicate whether these persons were officials of the state of Vermont or private persons. Id. at 118. The court, however, seemed to consider this distinction irrelevant to the disposition of the case. Id. at 121.

189. Id. at 118 .

190. Id. at 121-22.

191. 299 F. 1015 (W.D. Wash. 1924), affd sub nom. Unverzagt v. Benn, 5 F.2d 492 (9th Cir.), cert. denied, 269 U.S. 566 (1925).

192. Id. at 1016.

193. 8 F. Supp. 310 (N.D. Ill. 1934). 
examine such fact, and, if true, release the defendant. The court has no such power." 194 Finally, in Fiocconi v. Attorney General of the United States, ${ }^{195}$ the district court held that "[c]ourts are without power to remedy breaches of commitments among nations which are not the subject of treaty obligations."196

This limited view of judicial power, however, is inconsistent with the duty of Umited States courts to apply international law. In Paquete Habana ${ }^{197}$ the Supreme Court held that

[i]nternational law is part of our law, and must be ascertained and administered by the courts of justice of appropriate jurisdiction, as often as questions of right depending upon it are duly presented for their determination. For this purpose, where there is no treaty, and no controlling executive or legislative act or judicial decision, resort must be had to the customs and usages of civilized nations. ${ }^{198}$

Similarly, the Restatement (Third) of Foreign Relations states that "[c]ourts in the United States are bound to give effect to international law and international agreements . . ."199 As explained by the commentary, "The proposition that international law ... [is] law in the United States is addressed mainly to the courts."200 Paquete Habana thus provides United States courts with an explicit mandate to enforce customary international law in those cases in which to do so would not violate any domestic law or international agreement. ${ }^{201}$ In light of this command, domestic courts should

194. Id. at 313; see also United States v. Sobell, 142 F. Supp. 515, 523 (S.D.N.Y. 1956) (noting that a violation of international law is a matter between sovereigns), affd, 244 F.2d 520 (2d Cir.), cert. denied, 355 U.S. 873 (1957).

195. 339 F. Supp. 1242 (S.D.N.Y.), affd, 462 F.2d 475 (2d Cir.), cert. denied, 409 U.S. 1059 (1972).

196. Id. at 1247.

197. 175 U.S. 677 (1900).

198. Id. at 700 (emphasis added). Although The Paquete Habana is the most explicit endorsement of the power and duty of United States courts to apply international law, other Supreme Court cases also have recognized the obligation of domestic courts to enforce international law within the United States. In The Nereide, Bennett, Master, 13 U.S. (9 Cranch) 388, 423 (1815), the Court held that United States courts are "bound by the law of nations which is a part of the law of the land." In addition, the Court held, in United States v. Smith, 18 U.S. (5 Wheat.) 153, 160-61 (1820), that the "law of nations ... may be ascertained by consulting the works of jurists, writing professedly on public law; or by the general usage and practice of nations . . . "

199. 1 RESTATEMENT (THIRD) OF FOREIGN RELATIONS § 131(3) (1987).

200. 1 id. $\S 131 \mathrm{cmt}$. c.

201. See Harry A. Blackmun, The Supreme Court and the Law of Nations, 104 YALE 
reconsider their jurisprudence with respect to their power in cases of state-sponsored international abduction. Since customary international law requires the return of an abducted individual, federal courts should attempt to "administer" this customary international law remedy to the best of their ability. ${ }^{202}$

By its own terms, the rule of Paquete Habana allows customary international law to be superseded by contrary judicial decision, treaties, acts of Congress, and acts of the executive. However, two factors suggest that the threshold for determining that a judicial decision, treaty, or executive or legislative act is contrary should be fairly high. First, in Paquete Habana itself, the Court refused to infer a contrary domestic rule of law that was not clearly stated: the Court would not infer from treaty silence that coast fishing vessels were not protected from seizure in time of war. ${ }^{203}$

L.J. 39, 40 (1994) ("Although commentators continue to debate the extent of executive, legislative or judicial power to trump customary international law, the import of The Paquete Habana is clear: Customary international law informs the construction of domestic law, and, at least in the absence of any superceding positive law, is controlling.").

202. It is also encouraging that in the case of Dr. Alvarez-Machain, the federal district court thought that it had the power to order Dr. Alvarez-Machain's return. Once the district court had determined that the United States had violated the extradition treaty between the United States and Mexico, it held that international law required that the remedy for the breach "wipe out all the consequences of the illegal act." United States v. Caro-Quintero, 745 F. Supp 599, 614 (C.D. Cal. 1990), affd sub nom. United States v. Alvarez-Machain, 946 F.2d 1466 (9th Cir. 1991), rev'd, 112 S. Ct. 2188 (1992). Consequently, the court held that "It]he remedy in the present case is the immediate return of Dr. Machain to the territory of Mexico. Accordingly, the United States is hereby ordered to return him to the territory of Mexico." Id. If United States courts are equally empowered to remedy breaches of international agreements and customary international law, cf. Paquete Habana, 175 U.S. at 700 (holding that United States courts are to administer "international law" and drawing no distinction between conventional and customary international law), then domestic courts possess the authority to order the return of an abducted individual to an asylum state even in the absence of any breach of an international agreement, solely on the basis of a breach of customary international law. But see Brief for the United States at 29, United States v. Alvarez-Machain, 112 S. Ct 2188 (1992) (No. 91-712), available in LEXIS, Genfed Library, Briefs File (arguing that "[n]o provision of law grants to the courts the extraordinary power to repatriate a person").

203. Paquete Habana, 175 U.S. at 711.

The decision that enemy property on land, which by the modern usage of nations is not subject to capture as prize of war, cannot be condemned by a prize court, even by direction of the executive, without express authority from Congress, appears to us to repel any inference that coast fishing vessels, which are exempt by the general consent of civilized nations from capture, and which no act of Congress or order of the President has expressly authorized to be taken and confiscated, must be condemned by a prize court, for want of a distinct exId. emption in a treaty or other public act of the Government. 
In other words, any override of customary international law by a domestic law must be reasonably explicit.

Moreover, not every act by any executive branch official can be considered a controlling executive act that overrides international law. While there is certainly dispute as to whether the President may order a violation of international law, ${ }^{204}$ this power probably does not exist for lower level officials. Noting that in Paquete Habana, the act of an admiral did not override international law, the Eleventh Circuit held in Garcia-Mir v. Meese that "[a]t best, [Paquete Habana] suggests that lower level officials cannot by their acts render international law inapplicable."205

The second reason that the threshold for finding a domestic law to be contrary should be fairly high is derived from the Supreme Court case of The Schooner Charming Betsy, in which the Court noted that "[i]t has also been observed that an act of congress ought never to be construed to violate the law of nations if any other possible construction remains ...."206 This principle, recognizing as it does the important role of international law, has been construed to cover common law doctrines as well. ${ }^{207}$ In Gisbert v. Attorney General, the Fifth Circuit held that "[p]ublic international law has been incorporated into the common law of the United States ... and we are thus bound to construe the federal common law, to the extent reasonably possible, to avoid violating principles of public international law."208

The Ker-Frisbie doctrine, moreover, should not be considered a contrary "judicial decision" within the meaning of Paquete Habana and should not preclude domestic courts from ordering the return of an abducted person. The doctrine does not exphicitly

204. Compare Jonathan I. Charney, The Power of the Executive Branch of the United States Government to Violate Customary International Law, 80 AM. J. INT'L L. 913, 921 (1986) ("The President's special role in the United States Government . . . suggests that the President, acting alone, may have the authority under domestic law to place the United States in violation of customary international law.") with Louis Henkin, The President and International Lav, 80 AM. J. INT"L L. 930, 936 (1986) ("The President cannot disregard international law ... any more than he can disregard any other law.").

205. Garcia-Mir v. Meese, 788 F.2d 1446, 1454 (11th Cir.), cert. denied, 479 U.S. 889 (1986).

206. Murray v. The Schooner Charming Betsy, 6 U.S. (2 Cranch) 64, 118 (1804).

207. Schwabach \& Patchett, supra note 26, at 55.

208. Gisbert v. Attorney General, 988 F.2d 1437, 1447 (5th Cir. 1993); see also Garcia-Mir, 788 F.2d at 1453 (holding that "courts must construe American law so as to avoid violating principles of public international law"). 
contradict the international law rule, and its scope can be construed consistently with international law. In 1886, in Ker v. Illinois, ${ }^{209}$ the U.S. Supreme Court first considered the issue of international abduction. The defendant was wanted in Illinois on larceny charges. After he fled to Peru, a messenger was sent to retrieve him in accordance with the extradition treaty then in force between the United States and Peru. Instead, the messenger kidnapped Ker and forcibly returned him to the United States. ${ }^{210}$ The Court held that the abduction did not divest the district court of jurisdiction over the defendant. ${ }^{211}$ In Frisbie v. Collins, ${ }^{212}$ the Court extended the $\mathrm{Ker}$ holding to cases of interstate kidnapping. Taken together, the two cases have been said to "[recognize] jurisdiction over a defendant before the court regardless of how his presence was obtamed."213

United States courts that have considered the issue of international abduction have repeatedly relied on the Ker-Frisbie doctrine to justify exercising jurisdiction over defendants. ${ }^{214}$ However, while the exercise of jurisdiction is perfectly legitimate under KerFrisbie, nothing in the doctrine compels this result. Ker-Frisbie is merely a permissive doctrine; it allows, but does not require, courts to exercise jurisdiction notwithstanding irregularities or illegalities that have occurred during a defendant's arrest. Indeed, in $\mathrm{Ker}$ the Court held that

\footnotetext{
209. 119 U.S. 436 (1886).

210. Id. at 438.

211. Id. at 444.

212. 342 U.S. 519 (1952).

213. Abramovsky, supra note 9, at 158 .

214. See, e.g., United States ex rel. Lujan v. Gengler, 510 F.2d 62, 65 (2d Cir.), cert. denied, 421 U.S. 1001 (1975); United States v. Herrera, 504 F.2d 859, 860 (5th Cir. 1974). In fact, however, as shown before, every reported case of international abduction in which the United States has participated, with one exception, did not involve a breach of international law. See supra note 98 . In all of those cases, either the asylum state failed to protest the abduction or asylum state officials participated in the arrest. Therefore, although the courts were correct in relying on the Ker-Frisbie doctrine in exercising jurisdiction, these cases are not inconsistent with the thesis of this Note. The only case in which there was a breach of international law was the abduction of Dr. Alvarez-Machain. However, in that case, the issue of relying directly on the obligation of customary international law was never raised, as the case was argued in terms of whether the alleged breach of the extradition treaty defeated the jurisdiction of the court. See United States v. Caro-Quintero, 745 F. Supp. 599 (C.D. Cal. 1990), aff'd sub nom. United States v. Alvarez-Machain, 946 F.2d 1466 (9th Cir. 1991), rev'd, 112 S. Ct. 2188 (1992).
} 
[t]here are authorities of the highest respectability which hold that such forcible abduction is no sufficient reason why the party should not answer when brought within the jurisdiction of the court ....

However this may be, the decision of that question is as much within the province of the State court, as a question of common law, or of the law of nations, of which that court is bound to take notice, as it is of the courts of the United States. 215

Similarly, the language of Frisbie is no more compelling: "This Court has never departed from the rule announced in Ker v. Illinois ... that the power of a court to try a person for crime is not impaired by the fact that he had been brought within the court's jurisdiction by reason of a 'forcible abduction." "216 It would thus overextend the Ker-Frisbie doctrine to read it as requiring the exercise of jurisdiction and thereby precluding domestic courts from applying international law in cases of international abduction. ${ }^{217}$

A proper reading of the holding of the Court in Paquete Habana would permit domestic courts to order the return of an individual abducted in violation of international law. That is, if U.S. courts are to "administer" international law, they should effectuate the full extent of the customary international law remedy and order the executive to return the individual. It is unlikely, however, that U.S. courts will embrace this view anytime soon. U.S. courts have been notably reticent to involve themselves in what they perceive to be the purview of the executive branch. Thus, although it would certainly seem to be within their power to do so, U.S. courts are unlikely to order the return of an abducted individual based solely on customary international law. ${ }^{218}$

215. Ker, 119 U.S. at 444 (citations omitted).

216. Frisbie, 342 U.S. at 522 (emphasis added).

217. For an argument that Ker-Frisbie is inapplicable to cases of international abduction involving a breach of international law, see generally Schwabach \& Patchett, supra note 26 , at 21 .

218. In 1989, the U.S. Department of Justice issued an internal memorandum that assessed the power of the Federal Bureau of Investigation (FBI) to "apprehend and abduct a fugitive residing in a foreign state when those actions would be contrary to customary international law." Memorandum from William P. Barr, Authority of the Federal Bureau of Investigation to Override Customary or Other International Law in the Course of Extraterritorial Law Enforcement Activities 1 (June 21, 1989) (on file with 
A United States court not believing that the holding of Paquete Habana simply allowed it to order the repatriation of an abducted individual still might be able to "administer" international law by refusing to exercise jurisdiction over a criminal defendant brought before the court in violation of international law. Through their supervisory power, federal courts may choose to dechne to exercise jurisdiction. In United States v. Toscanino, ${ }^{219}$ the Second Circuit held that it could "rely ... upon [its] supervisory power over the administration of criminal justice" in choosing to decline to exercise jurisdiction in a case in which the defendant allegedly had been extensively tortured in the course of an international abduction. ${ }^{220}$ The basis for this supervisory power is that a court has no obligation to allow itself to become an "accomplicel in willful disobedience of law."221 This reasoning could be applied to state-sponsored international abductions generally: recognizing that these abductions violate some of the most basic norms of international law and that international custom requires that a state return an abducted individual, a federal court could use its supervisory power to refuse to exercise jurisdiction over the defendant. ${ }^{222}$ The court could thereby facilitate the return of the indi-

Office of Legal Counsel, U.S. Department of Justice). The Barr memorandum concluded that the Department had "erred" in 1980 in concluding that the FBI lacked such authority. The memorandum concluded first that the FBI could arrest persons even if those actions violated international law, and second that the President "has inherent constitutional authority to order the FBI to investigate and arrest individuals in a manner that departs from international law." Id. This opinion, however, does not constitute a contrary executive decision, because an internal memorandum is not "law" that domestic courts must apply. This memorandum simply evaluated whether, in the Department's opinion, "the FBI has legal authority to carry out law enforcement operations that contravene international law." Id. at 2.

Moreover, in deciding that "legal authority" existed, the memorandum certainly did not authorize an executive policy of such abductions. Consequently, the courts are not bound by the Department's conclusions as to the scope of FBI authority. In short, the Barr memorandum is not an executive act that precludes United States courts from administering customary international law in abduction cases. It is also worth noting that in the wake of the abduction of Dr. Alvarez-Machain and the outrage expressed by Mexico, President Clinton promised not to allow the kidnapping of foreign nationals in the future. John Guendelsberger, Two Kinds of Federal Kidnapping, ThE PLAIN DEALER, July 2, 1993, at 5B.

219. 500 F.2d 267 (2d Cir. 1974).

220. Id. at 276.

221. United States v. Caro-Quintero, 745 F. Supp. 599, 615 (C.D. Cal. 1990) (quoting McNabb v. United States, 318 U.S. 332, 345 (1943)), affd sub nom. United States v. Alvarez-Machain, 946 F.2d 1466 (9th Cir. 1991), rev'd, 112 S. Cl. 2188 (1992).

222. Cf. 4B Op. Off. Legal Counsel 543, 549 (1980) (noting that the Second Circuit 
vidual and bring the United States into conformity with its international law obligations. ${ }^{223}$ Further, if the judiciary were to adopt this position, it would certainly reduce the likelihood that the executive would undertake such abductions. ${ }^{224}$ This position would thus help to support a world order in accord with the rule of international law and also help to eliminate the political tensions that inevitably accompany such abductions. ${ }^{225}$

Nonetheless, even if United States courts choose to leave the responsibility of ensuring compliance with international law to the executive branch, this does not mean that return is discretionary. International law obliges the state to return the individual and specifically addresses neither the executive nor the judiciary. Whetler, in practice, the functional application of this obligation should lie with the judicial or the executive branch is thus purely a matter of domestic policy and law. ${ }^{226}$ However, given the unlikelihood that the same executive branch that violated international law in abducting the individual will abide by its international obligations in terms of returning the individual, the judiciary may be the more appropriate body to perform this function.

Some may argue that returning an abductee who is accused, or even indicted, of a crime against the United States is too high a price to pay in the name of adherence to customary international

"has explicitly declined to define the implications of an international law violation on criminal jurisdiction" and suggesting that the court might decline jurisdiction based on the violation of international law).

223. The South African Supreme Court, for example, has held that in cases of a state-sponsored international abduction, courts should refuse to exercise their criminal jurisdiction over a defendant. S v. Ebrahim, 1991 (2) SA 553 (S. Afr.), reprinted in S. Afr. L. Rep. (Apr.-June 1991).

224. Cf. 4B Op. Off. Legal Counsel 543, 557 (1980) ("Only if foreign nationals, without U.S. direction or compensation, deposited the fugitive on American soil would the legal problems in this memorandum be obviated by their presence.").

225. The abduction of Dr. Alvarez-Machain created severe political tension between the United States and many of its regional neighbors. Mexico, for example, repudiated the ruling in Alvarez-Machain as "invalid and illegal," and the Jamaican minister for security and justice denounced the decision as "an atrocity that would disturb the world." Stewart, supra note 94, at 50 .

226. Preuss, for example, writes,

Under the law of a given state the courts may be incompetent to release a prisoner who has been arrested by state agents in violation of a foreign sovereignty. It does not follow that the arresting state is under no obligation to restore the prisoner to the state of asylum. Whether the appropriate action is taken by the judiciary or by the executive department would seem to be purely a matter of municipal concern.

Preuss, supra note 21, at 505 n.15. 
law. However, three reasons temper the acknowledged problem. First, just as process is important within the reach of the Constitution, process is important outside of it as well. Process does not suddenly become unimportant simply because the alleged criminal is not within our borders. The United States should acknowledge the international community's desire that the transfers of persons from one country to another be orderly, subject to the consent of the sovereign powers involved. ${ }^{27}$ Second, international agreements can help ensure that alleged criminals will not forever elude trials. Extradition treaties can be signed that require that the asylum state either extradite or prosecute alleged criminals. ${ }^{228}$ Third, international abduction is a two-way street, and a rule that prohibits abduction and requires return protects U.S. citizens at the same time that it protects foreigners. It helps protect U.S. citizens from the vagaries of foreign justice systems and foreign criminal codes that are totally inconsistent with notions of criminal responsibility in the United States. ${ }^{229}$

\section{CONCLUSION}

Without a doubt, state-sponsored international abductions will continue in the future as states, frustrated by the inability to punish those they deem deserving, continue to resort to self-help methods of apprehension. Standing between such states and this anarchy is the rule of international law. Long experience with international abductions has led the international community to develop a customary international law that requires the return of an abducted individual when the abductor's actions are attributable to the abducting state, the asylum state does not consent, and the asylum state demands the return of the individual. Although the very consistency of state practice attests to the seriousness with which states view the issue of state-sponsored international abduction, United States jurisprudence has so far failed to acknowledge

227. However, to the extent that the doctrine of self-defense develops to work within this prohibition of international abduction, a consensus may eventually emerge that permits exactly these types of abduction in cases that can legitimately be defended on the basis of "self-defense." See Findlay, supra note 9, at 25-33; see supra note 48.

228. See, e.g., Treaty on Extradition, May 4, 1978, U.S.-Mex., art. 9, 31 U.S.T. 5059, 5065.

229. See supra note 9. 
the requirements that international law imposes, focusing instead on the question of jurisdiction alone.

The abduction of Dr. Alvarez-Machain was probably not the last time that the United States will violate international law. And with the United States as the leader, it is only a question of time before other countries follow. United States courts can administer international law and stymie this trend toward lawlessness either by affirmatively ordering the return of abducted individuals or, less directly, by refusing to recognize jurisdiction in cases when international law has clearly been violated. Indeed, it is ironic that South Africa is leading the way in such compliance with international law. ${ }^{230}$ It is time for the United States to conform to the requirements of international law and refrain from undertaking international abductions. Failing this, in cases of international abduction sponsored by the executive branch, it is time for the United States judiciary to properly apply international law "as often as questions of right depending on it are duly presented for their determination."231

230. See supra note 223.

231. The Paquete Habana, 175 U.S. 677, 700 (1900). 
